\title{
Guiding Requirements for Designing Life Support System Architectures for Crewed Exploration Missions beyond Low-Earth Orbit
}

\author{
Jay L. Perry ${ }^{1}$ \\ NASA Marshall Space Flight Center, Huntsville, Alabama 35812, USA \\ Miriam J. Sargusingh ${ }^{2}$ \\ NASA Johnson Space Center, Houston, Texas 77058, USA \\ and \\ Nikzad Toomarian ${ }^{3}$ \\ NASA Jet Propulsion Laboratory, Pasadena, California 91109, USA
}

\begin{abstract}
The National Aeronautics and Space Administration's (NASA) technology development roadmaps provide guidance to focus technological development in areas that enable crewed exploration missions beyond low-Earth orbit. Specifically, the technology area roadmap on human health, life support and habitation systems describes the need for life support system (LSS) technologies that can improve reliability and in-flight maintainability within a minimally-sized package while enabling a high degree of mission autonomy. To address the needs outlined by the guiding technology area roadmap, NASA's Advanced Exploration Systems (AES) Program has commissioned the Life Support Systems (LSS) Project to lead technology development in the areas of water recovery and management, atmosphere revitalization, and environmental monitoring. A notional exploration LSS architecture derived from the International Space has been developed and serves as the developmental basis for these efforts. Functional requirements and key performance parameters that guide the exploration LSS technology development efforts are presented and discussed. Areas where LSS flight operations aboard the ISS afford lessons learned that are relevant to exploration missions are highlighted.
\end{abstract}

\section{Nomenclature}

$\begin{array}{ll}A R & =\text { atmosphere revitalization } \\ C F U & =\text { colony forming unit } \\ C M & =\text { crewmember } \\ C W S & =\text { caution and warning system } \\ D R A 5 & =\text { Design Reference Architecture 5.0 } \\ E A W G & =\text { Exploration Atmospheres Working Group } \\ E C L S & =\text { environmental control and life support } \\ E H S & =\text { environmental health system } \\ E M & =\text { environmental monitoring } \\ E V A & =\text { extravehicular activity } \\ G E R & =\text { Global Exploration Roadmap } \\ G E S & =\text { Global Exploration Strategy } \\ I S E C G & =\text { International Space Exploration Coordination Group } \\ I S S & =\text { International Space Station }\end{array}$

${ }^{1}$ Lead Aerospace Engineer, ECLS Systems, Space Systems Dept., Mail Stop ES62.

${ }^{2}$ Aerospace Engineer, ECLS Systems, Crew and Thermal Systems Division, Mail Stop EC2.

${ }^{3}$ Manager, Environmental Monitoring Systems, Instruments Division, Mail Stop 321-520. 


$\begin{array}{ll}\text { LEO } & =\text { low-Earth orbit } \\ L S S & =\text { life support system } \\ N A S A & =\text { National Aeronautics and Space Administration } \\ N T U & =\text { nepholometric turbidity unit } \\ P C U & =\text { platinum-cobalt unit } \\ \text { SMAC } & =\text { spacecraft maximum allowable concentration } \\ S W E G & =\text { spacecraft water exposure guideline } \\ T I C & =\text { total inorganic carbon } \\ T O C & =\text { total organic carbon } \\ T O N & =\text { threshold odor number } \\ T T N & =\text { threshold taste number } \\ W M & =\text { waste management } \\ W R M & =\text { water recovery and management } \\ g & =\text { gram } \\ h & =\text { hour } \\ k g & =\text { kilogram } \\ k P a & =\text { kilopascal } \\ L & =\text { liter } \\ m & =\text { meter } \\ m g & =\text { milligram } \\ m L & =\text { milliliter } \\ m m & =\text { millimeter } \\ M P a & =\text { megapascal } \\ t & =\text { mission duration } \\ V_{u} & =\text { volume of urine } \\ \mu m & =\text { micrometer } \\ & \end{array}$

\section{Introduction}

$\mathrm{R}$ EALIZING the vision of the Global Exploration Strategy (GES) developed by the fourteen national space agencies of the International Space Exploration Coordination Group (ISECG) requires careful planning and collaboration to achieve needed technological advancement and development. ${ }^{1}$ Five themes contained in the GES include developing new knowledge in science and technology, enabling a sustained human presence in space and extending exploration frontiers, fostering space-related economic expansion, nurturing global partnerships, and educating and inspiring people worldwide. These themes encompass the benefits associated with exploring space and are similar to goals contained in the United States' 2010 space exploration policy which calls for strengthening and expanding international partnerships to mutually beneficial initiatives that are mutually beneficial space development and exploration initiatives. ${ }^{2}$ This policy also calls for pursuing both crewed and robotic exploration missions of the solar system and regions beyond that are inspirational, lead to better understanding of Earth, spur scientific discovery, and foster new technologies and new industries. Relating to exploration, the policy calls for crewed missions beyond the moon by 2025 and missions to Mars by the mid-2030s. ${ }^{3}$ The ISECG-developed Global Exploration Roadmap (GER), originally released in 2011 and updated in 2013, expands on the GES's themes by defining an exploration path that culminates in crewed exploration missions to Mars. ${ }^{4}$ More recently, NASA developed a threephased approach to Mars exploration that aligns with the ISCEG-developed GER. ${ }^{5}$

\section{A. Preparing for the Exploration Challenge}

Within this international context, the National Aeronautics and Space Administration (NASA) has accomplished design reference mission studies, technical needs assessments, and technical area roadmap development to guide technology development efforts conducted by projects focused on enabling technological gaps. The Mars Design Reference Architecture 5.0 (DRA5) was documented in 2009 and updated in 2014.$^{6-8}$ Missions to Mars are the most challenging exploration objectives for crewed exploration within the exploration framework. The exploration objectives build incrementally toward missions to Mars and, therefore, Mars missions serve as the basis for technology development.

Among the top technical challenges for crewed exploration beyond low-Earth orbit (LEO) is the need for a highly reliable, maintainable environmental control and life support (ECLS) system. ${ }^{9}, 10$ The technical area roadmap on human health, life support, and habitation systems more specifically outlines technical advancements that are needed 
for the ECLS systems that will make crewed missions to Mars and beyond a reality. ${ }^{11}$ Specific focal areas identified in the technical area roadmap that are of interest to ECLS system technology developers include atmosphere revitalization (AR), water recovery and management (WRM), waste management (WM), and environmental monitoring $(\mathrm{EM}) .^{12}$

\section{B. Considering Lessons Learned from the International Space Station}

Figure 1 presents a simplified life support system (LSS) architecture that is based on the process technologies used aboard the International Space Station (ISS). This architecture builds upon the core process technologies and the significant operational record of the ISS LSS. ${ }^{13-15}$ Specific developmental aspects of the exploration LSS architecture, including key performance parameters, and key functional interfaces within the architecture are presented elsewhere. ${ }^{16,} 17$ The ISS LSS development and operational heritage offers invaluable observations and lessons learned in the areas of design, development, testing, in-flight operations and refinement, and international collaboration. The appendix, based on a review of conference proceedings between 2000 and 2016, lists documentation for relevant technical areas from which LSS development for exploration missions may benefit. As exploration missions become increasingly well-defined through Phase A development, these insights will prove invaluable to expediting the exploration mission program's life cycle.

Process technologies for exploration missions may be borrowed directly or evolved from those used aboard the ISS. More recent technical advances may be incorporated to address the future exploration mission technical needs and demands. As a first step toward future exploration goals, the ISS provides a wealth of information on core LSS process technology performance spanning over a decade. The ISS also serves as a laboratory for demonstrating exploration-class LSS equipment. In the unique ISS environment the equipment performance can be evaluated and operational strategies suitable for exploration missions can be tested. Efforts to use the ISS as an LSS technology demonstration platform are progressing.

The technological development to address exploration mission needs, with emphasis on a mission to Mars as the greatest challenge, is closing the gap toward implementing the exploration roadmap. ${ }^{18-20}$ These developmental efforts are guided by the Mars DRA5, the NASA Space Flight Human-System Standard (NASA-STD-3001, Vol. 2) and the Human Integration Design Handbook (NASA/SP-2010-3407). Technical guidance derived from these sources is presented by the following narrative.

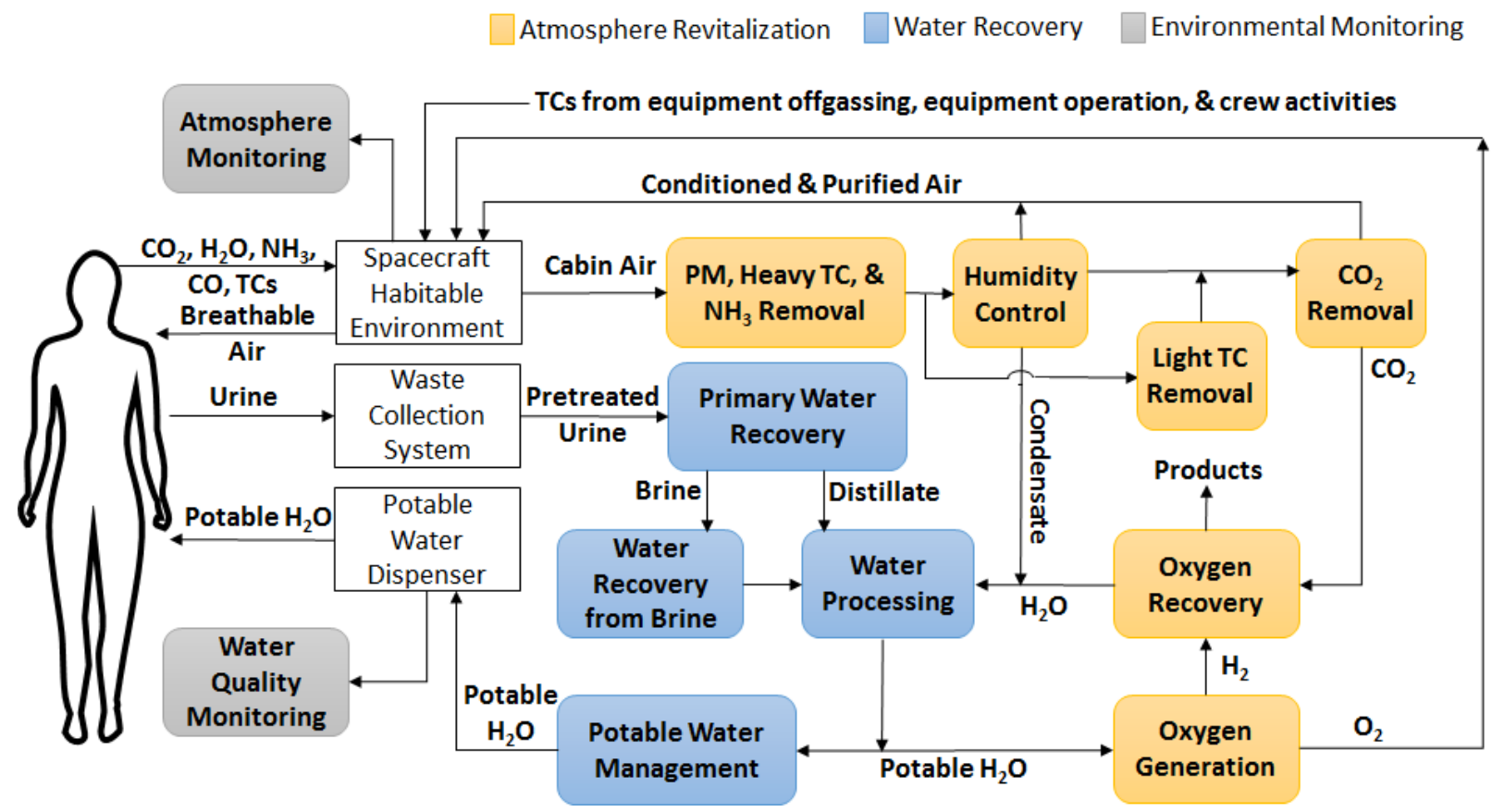

Figure 1. A simplified LSS block diagram for exploration missions. Subsystems provide functionality for atmosphere revitalization; water recovery, purification, and management; and environmental monitoring. 


\section{General Guiding Requirements for an Exploration Life Support System}

Guiding functional requirements are essential for developing the LSS architecture and selecting suitable improvements in core process technologies. As the framework for the exploration roadmap continues to develop, this guidance provides needed focus for technology development efforts in advance of formal exploration program formulation. General guiding requirements address areas such as mission duration, crew size, habitat size, and extravehicular activity (EVA) frequency which can impact all subsystems within the exploration LSS architecture. This guidance is found in the Mars DRA5.

\section{A. Mission Duration Guidance}

Missions evaluated within the Mars DRA5 framework include opposition-class and conjunction-class round trip missions. The former mission type requires short Mars surface stays in the range of 30 days to 90 days while the latter requires long surface stays ranging between 475 days and 540 days. ${ }^{21}$ The round trip transit time between Earth and Mars ranges between 400 days and 650 days for opposition-class missions while a round trip for conjunction-class missions ranges between 360 days and 420 days. Including the surface stay, an opposition-class mission total duration is $\sim 500$ days to $\sim 630$ days. A conjunction-class mission total duration is $\sim 830$ days to $\sim 960$ days. ${ }^{22}$ From an LSS development perspective, preparing for the longest round trip transit time of $\sim 650$ days and the longest stay in the Mars vicinity of $\sim 540$ days is prudent.

\section{B. Crew Size Guidance}

The Mars DRA5 study evaluated the merits of various crew sizes. ${ }^{23} \mathrm{~A}$ crew of four was found to be operationally sufficient and most economical from a mission infrastructure perspective relating to vehicle size, LSS infrastructure, and propulsion needs. Yet, expanding the crew size to six had merit for addressing mission objectives and addressing risk. As the most economical crew size, a crew of four is the exploration LSS developmental basis. Expanding the crew to six should be used to bound functional margins for the LSS.

\section{Habitat Size Guidance}

The 2014 Mars DRA5 update evaluated deep space habitat sizing. ${ }^{24}$ This evaluation provided guidance on the deep space habitat pressurized volume of $\sim 280 \mathrm{~m}^{3}$ which is to provide $\sim 24 \mathrm{~m}^{3}$ habitable volume per crewmember (CM). Various deep space habitat concepts are under evaluation with pressurized volumes up to $662 \mathrm{~m}^{3}$ providing nearly $130 \mathrm{~m}^{3}$ of habitable volume per CM. ${ }^{25}$ The smaller pressurized volume is the more challenging from an LSS development perspective relative to system packaging and dynamic response times and serves as the basis for development.

\section{Extravehicular Activity Guidance}

Limitations on surface exploration EVA frequency and duration presented in the Mars DRA5 are useful for bounding an upper range for the number of surface exploration EVA events that must be supported by the LSS. Each CM is limited to 12 hours of EVA in a 48-hour period and 24 hours of EVA over a 7-day period. ${ }^{26}$ The typical EVA duration is six hours. Under these limitations, a crew of four could execute up to 16 individual EVA events or eight 2-CM EVA events each week. Over a 71-week surface stay, a total of 1136 individual EVA events or 5682 CM EVA events are possible. The LSS must support these EVA operations by replenishing oxygen $\left(\mathrm{O}_{2}\right)$ tanks and providing water $\left(\mathrm{H}_{2} \mathrm{O}\right)$. Resource losses through carbon dioxide $\left(\mathrm{CO}_{2}\right)$ and $\mathrm{H}_{2} \mathrm{O}$ venting from the mobile LSS must also be accommodated. During transit periods, EVA is limited to contingency purposes. ${ }^{27}$

\section{Atmosphere Revitalization}

The AR subsystem maintains the cabin atmospheric composition and quality within specified parameters. A general overview is provided for an exploration LSS AR subsystem. Functional requirement guidance from NASASTD-3001, NASA/SP-2010-3407, and relevant supporting documentation is presented.

\section{A. AR Subsystem Exploration Architecture Overview}

Figure 2 depicts a simplified block diagram for an exploration AR subsystem. Functions included in the AR subsystem include particulate matter removal, trace chemical contaminant removal, $\mathrm{CO}_{2}$ removal, cabin atmosphere composition control, $\mathrm{O}_{2}$ supply, and resource recovery. The AR subsystem depends on an efficient cabin ventilation system to receive process air and distribute purified air. Potable water from the WRM subsystem to electrolyze to supply oxygen is a key interface. By employing a $\mathrm{CO}_{2}$ reduction process technology, the AR subsystem can return 
some of the water to the WRM. The AR subsystem also interfaces with the EM subsystem to control the cabin atmospheric composition and monitor trace contaminant concentrations.

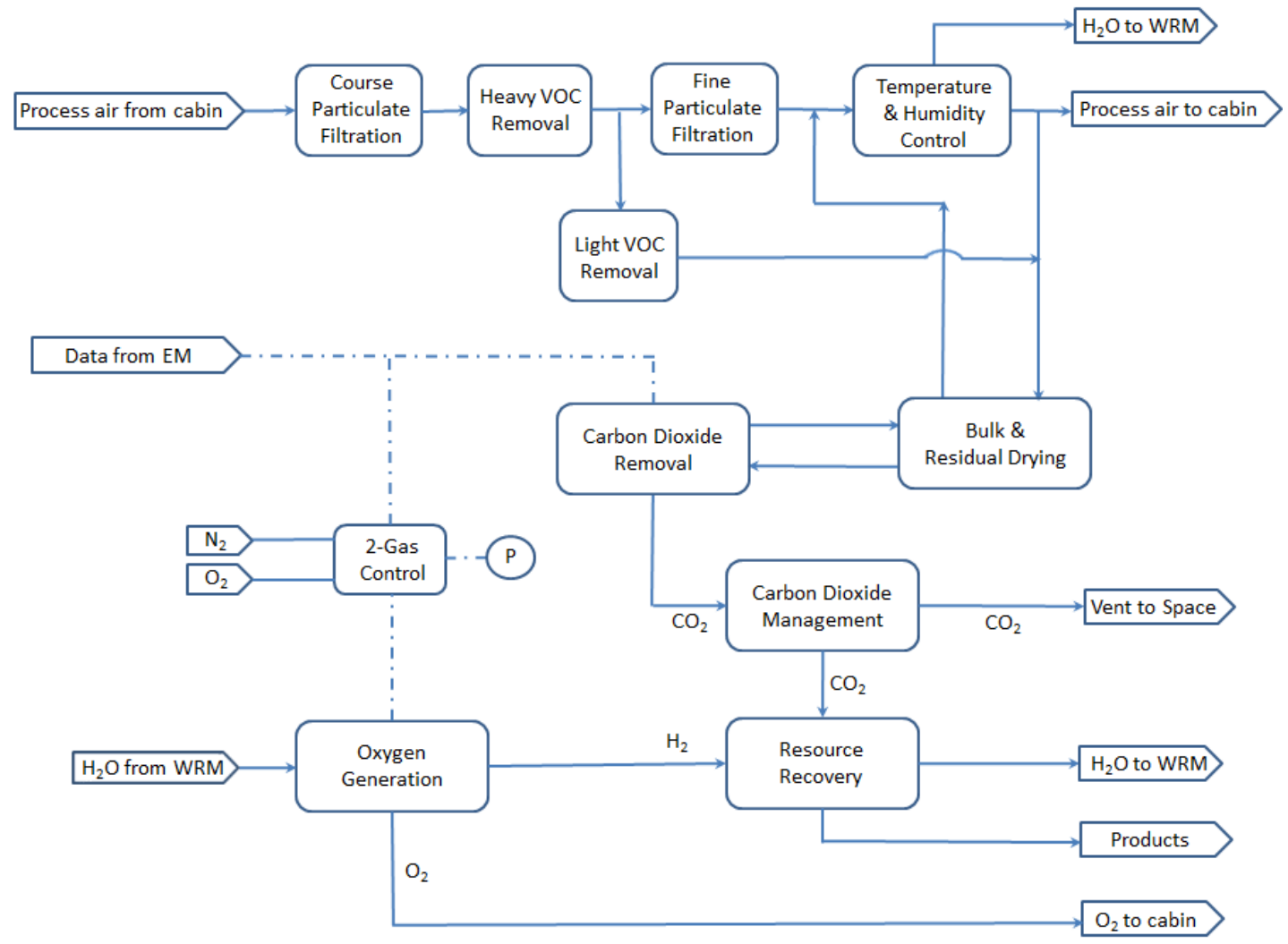

Figure 2. An AR subsystem simplified block diagram for exploration missions.

\section{B. AR Subsystem Performance Guidance}

The AR subsystem must be capable of handling the single person daily loads of $\mathrm{H}_{2} \mathrm{O}$ and $\mathrm{CO}_{2}$ while satisfying the demand for $\mathrm{O}_{2}$. Simple 24-hour average metabolic loads for a single $\mathrm{CM}$ derived from Table 1 are $0.083 \mathrm{~kg}$ $\mathrm{H}_{2} \mathrm{O} / \mathrm{h} \mathrm{H} \mathrm{H}_{2} \mathrm{O}, 0.047 \mathrm{~kg} \mathrm{CO} / \mathrm{h}, 0.038 \mathrm{~kg} \mathrm{O} / \mathrm{h} .{ }^{28}$ In LSS design, the daily variation and range must be understood and the design must be sufficiently robust to maintain the cabin conditions within specifications despite daily variation in the metabolic loads and demands.

\section{Carbon Dioxide and Trace Contaminant Control}

Carbon dioxide and trace contaminants must comply with the spacecraft maximum allowable concentrations (SMAC) documented in Spacecraft Maximum Allowable Concentrations for Airborne Contaminants (JSC 20584). ${ }^{29}$ Exploration missions can exceed 500 days and approach 1000 days in duration. Therefore the 1000-day SMACs apply. The 180-day SMACs apply for com-
Table 1. Metabolic loads and demands.*

\begin{tabular}{|c|l|c|}
\hline COMPOUND & \multicolumn{1}{|c|}{ ACTIVITY } & $\begin{array}{c}\text { RATE } \\
\text { (kg/CM-h) }\end{array}$ \\
\hline \multirow{4}{*}{$\mathrm{H}_{2} \mathrm{O}$} & Sleep & 0.0378 \\
\cline { 2 - 3 } & Normal & 0.0706 \\
\cline { 2 - 3 } & Exercise & 0.629 \\
\cline { 2 - 3 } & Post Exercise & 0.281 \\
\hline \multirow{3}{*}{$\mathrm{CO}_{2}$} & Sleep & 0.027 \\
\cline { 2 - 3 } & Normal/Post Ex. & 0.047 \\
\cline { 2 - 3 } & Exercise & 0.3 \\
\hline \multirow{3}{*}{$\mathrm{O}_{2}$} & Sleep & 0.022 \\
\cline { 2 - 3 } & Normal/Post Ex. & 0.038 \\
\cline { 2 - 3 } & Exercise & 0.24 \\
\hline
\end{tabular}

*Single CM. pounds that have no documented 1000-day SMAC. The average $\mathrm{CO}_{2}$ load is listed in Table 1. Table 2 summarizes the trace contaminant control load. ${ }^{30}$ Trace contaminant control design details are provided by Refs. 31 and 32 .

Recent developments pertaining to the need to control the $\mathrm{CO}_{2}$ partial pressure to levels well below the published 1000-day SMAC of $8990 \mathrm{mg} / \mathrm{m}^{3}\left(3.8 \mathrm{~mm} \mathrm{Hg}\right.$ ) must be considered. ${ }^{33,34}$ Controlling to $\mathrm{CO}_{2}$ concentrations <4730 $\mathrm{mg} / \mathrm{m}^{3}(2 \mathrm{~mm} \mathrm{Hg})$ may be necessary if crew health and performance observations aboard the ISS are confirmed by ground-based studies. ${ }^{35}$ 
Table 2. Chemical load for trace contaminant control design.

\begin{tabular}{|l|l|c|c|}
\hline \multicolumn{2}{|c|}{ CONTAMINANT NAME } & \multicolumn{2}{c|}{ GENERATION RATE $^{a}$} \\
\hline IUPAC & \multicolumn{1}{|c|}{ COMMON } & $\begin{array}{c}\text { OFFGASSING } \\
(\mathrm{mg} / \text { day-kg }\end{array}$ & $\begin{array}{c}\text { METABOLIC } \\
(\mathrm{mg} / \text { day-person })\end{array}$ \\
\hline Methanol & Methyl alcohol & $1.3 \times 10^{-3}$ & 0.9 \\
\hline Ethanol & Ethyl alcohol & $7.8 \times 10^{-3}$ & 4.3 \\
\hline n-butanol & Butyl alcohol & $4.7 \times 10^{-3}$ & 0.5 \\
\hline Methanal & Formaldehyde & $4.4 \times 10^{-6}$ & 0.4 \\
\hline Ethanal & Acetaldehyde & $1.1 \times 10^{-4}$ & 0.6 \\
\hline Benzene & Benzol & $2.5 \times 10^{-5}$ & 2.2 \\
\hline Methylbenzene & Toluene & $2 \times 10^{-3}$ & 0.6 \\
\hline Dimethylbenzenes & Xylenes & $3.7 \times 10^{-3}$ & 0.2 \\
\hline Furan & Divinylene oxide & $1.8 \times 10^{-6}$ & 0.3 \\
\hline Dichloromethane & Methylene chloride & $2.2 \times 10^{-3}$ & 0.09 \\
\hline 2-propanone & Acetone & $3.6 \times 10^{-3}$ & 19 \\
\hline Trimethylsilanol & Trimethyhydroxysilane & $1.7 \times 10^{-4}$ & 0 \\
\hline Hexamethylcyclotrisiloxane & D3 siloxane & $1.7 \times 10^{-4}$ & 0 \\
\hline Azane & Ammonia & $8.5 \times 10^{-5}$ & 50 \\
\hline Carbon monoxide & Carbonous oxide & $2 \times 10^{-3}$ & 18 \\
\hline Hydrogen & Dihydrogen & $5.9 \times 10^{-6}$ & 42 \\
\hline Methane & Carbane & $6.4 \times 10^{-4}$ & 329 \\
\hline a. Supplemented by system sources as they are identified. b. Offgassing rate is for the mass of internal, non-structural equipment.
\end{tabular}

\section{Particulate Matter Control}

The particulate matter introduced into the habitable environment typically consists of fabric lint, skin fragments, hair, food debris, and paper and plastic debris. ${ }^{36}$ For missions longer than 14 days, particulate matter suspended in the cabin atmosphere must be controlled to $<1 \mathrm{mg} / \mathrm{m}^{3}$ for the size range of $0.5 \mu \mathrm{m}$ to $10 \mu \mathrm{m}$ (respirable fraction) and $<3 \mathrm{mg} / \mathrm{m}^{3}$ for the size range of $10 \mu \mathrm{m}$ to $100 \mu \mathrm{m}$. The generation load that must be controlled ranges between 0.6 $\mathrm{mg} /$ person-minute and $1.6 \mathrm{mg} /$ person-minute. ${ }^{37}$ More details on the challenges and design considerations for particulate matter control are presented in Ref. 36. Along with particulate matter, airborne microbial levels must be maintained to $<100 \mathrm{CFU}$ fungus $/ \mathrm{m}^{3}$ and $<1000 \mathrm{CFU}$ bacteria $/ \mathrm{m}^{3}$. The generation rate for both bacteria and fungi is $1640 \mathrm{CFU} /$ person-minute. ${ }^{38}$

Dust intrusion into the surface habitat during EVA activities must be considered. Using lunar regolith as a current basis, the suspended surface dust $<10 \mu \mathrm{m}$ must be maintained below $0.3 \mathrm{mg} / \mathrm{m}^{3}$ for episodic exposures over a 6month period. ${ }^{39}$ The expected surface dust load for this size range is estimated to be $\sim 15.9$ grams/EVA CM. This dust intrusion rate increases the basic particulate load by approximately a factor of seven. Dust intrusion barriers that approach $99 \%$ effectiveness may be very important to surface exploration operations.

3. Oxygen Supply

Beyond satisfying the $\mathrm{O}_{2}$ demand in Table 1, the AR must accommodate the $\mathrm{O}_{2}$ necessary to support EVA and medical operations. A capability to supply high purity $\mathrm{O}_{2}$ at $24.8 \mathrm{MPa}$ to recharge the mobile LSS tanks and support medical $\mathrm{O}_{2}$ requirements must be provided. The $\mathrm{O}_{2}$ purity required may range between $99.5 \%$ and $99.989 \%$ depending on the use.

\section{Cabin Pressure and Composition Control}

Cabin pressure must be controlled between $20.7 \mathrm{kPa}$ and $103 \mathrm{kPa}$ and an inert diluent gas must be provided for mission durations $>2$ weeks. ${ }^{40}$ The oxygen partial pressure must be maintained between $20.7 \mathrm{kPa}$ and $50.6 \mathrm{kPa}$ depending on the cabin total pressure. ${ }^{41}$ The NASA Exploration Atmospheres Working Group (EAWG) has recommended $101.3 \mathrm{kPa}$ total pressure and $21.3 \mathrm{kPa} \mathrm{O}$ partial pressure for exploration mission design. ${ }^{42} \mathrm{An}$ update by the EAWG in 2013 included the allowance for mission architectures with high-frequency EVA demands to have the capability to operate at $56.5 \mathrm{kPa}$ total pressure and $34 \% \mathrm{O}_{2}$ partial pressure. Exploration LSS developmental efforts have been working within the $101.5 \mathrm{kPa}$ total pressure and $21 \% \mathrm{O}_{2}$ partial pressure guidance. 


\section{Cabin Temperature and Humidity Control}

The AR subsystem interfaces with cabin ventilation, temperature, and humidity control equipment. Cabin temperature conditions must be maintained between $18{ }^{\circ} \mathrm{C}$ and $27^{\circ} \mathrm{C}$ and the humidity must be controlled between $25 \%$ and $75 \%$.

6. Resource Recovery Performance Goals

As shown by Fig. 2, the AR subsystem receives $\mathrm{H}_{2} \mathrm{O}$ from the potable supply to produce $\mathrm{O}_{2}$. By employing a resource recovery technology, $\mathrm{H}_{2} \mathrm{O}$ can be returned to the vehicle to minimize the net mission $\mathrm{H}_{2} \mathrm{O}$ demand. Resource recovery technologies can also minimize overboard venting losses. The goals for the long duration transit phase is to recovery $>75 \%$ of the $\mathrm{O}_{2}$ from $\mathrm{CO}_{2}$. A more challenging goal to reach $>90 \% \mathrm{O}_{2}$ recovery from $\mathrm{CO}_{2}$ applies to surface exploration mission phases. Resource losses due to venting must be reduced to $<10 \%$.

\section{Water Recovery and Management}

The WRM subsystem manages the water resources for the exploration mission. A general overview is provided for an exploration LSS WRM subsystem. Functional requirement guidance from NASA-STD-3001, NASA/SP2010-3407, and relevant supporting documentation is presented.

\section{A. WRM Subsystem Exploration Architecture Overview}

Figure 3 depicts a simplified block diagram of an exploration WRM subsystem. The WRM subsystem, which consists of wastewater collection, primary $\mathrm{H}_{2} \mathrm{O}$ recovery, $\mathrm{H}_{2} \mathrm{O}$ purification, brine post-processing, and potable $\mathrm{H}_{2} \mathrm{O}$ storage and distribution elements, must manage the water resources for the mission. The WRM subsystem extracts $\mathrm{H}_{2} \mathrm{O}$ from waste and various wastewater streams and purifies it to potable standards in order to minimize the total $\mathrm{H}_{2} \mathrm{O}$ mass required for an exploration mission. The potable $\mathrm{H}_{2} \mathrm{O}$ is distributed for the crew's use for drinking, food rehydration, personal hygiene, and medical needs. The WRM subsystem also provides potable $\mathrm{H}_{2} \mathrm{O}$ to the AR subsystem for $\mathrm{O}_{2}$ production and receives a fraction of that $\mathrm{H}_{2} \mathrm{O}$ in return from the $\mathrm{CO}_{2}$ reduction process. The primary functional objective of the exploration WRM is to achieve $>98 \%$ overall water recovery. Specific objectives include recovering $>85 \% \mathrm{H}_{2} \mathrm{O}$ from urine, $>95 \%$ of $\mathrm{H}_{2} \mathrm{O}$ from brine, and having the capability to survive dormancy periods of at least 500 days.

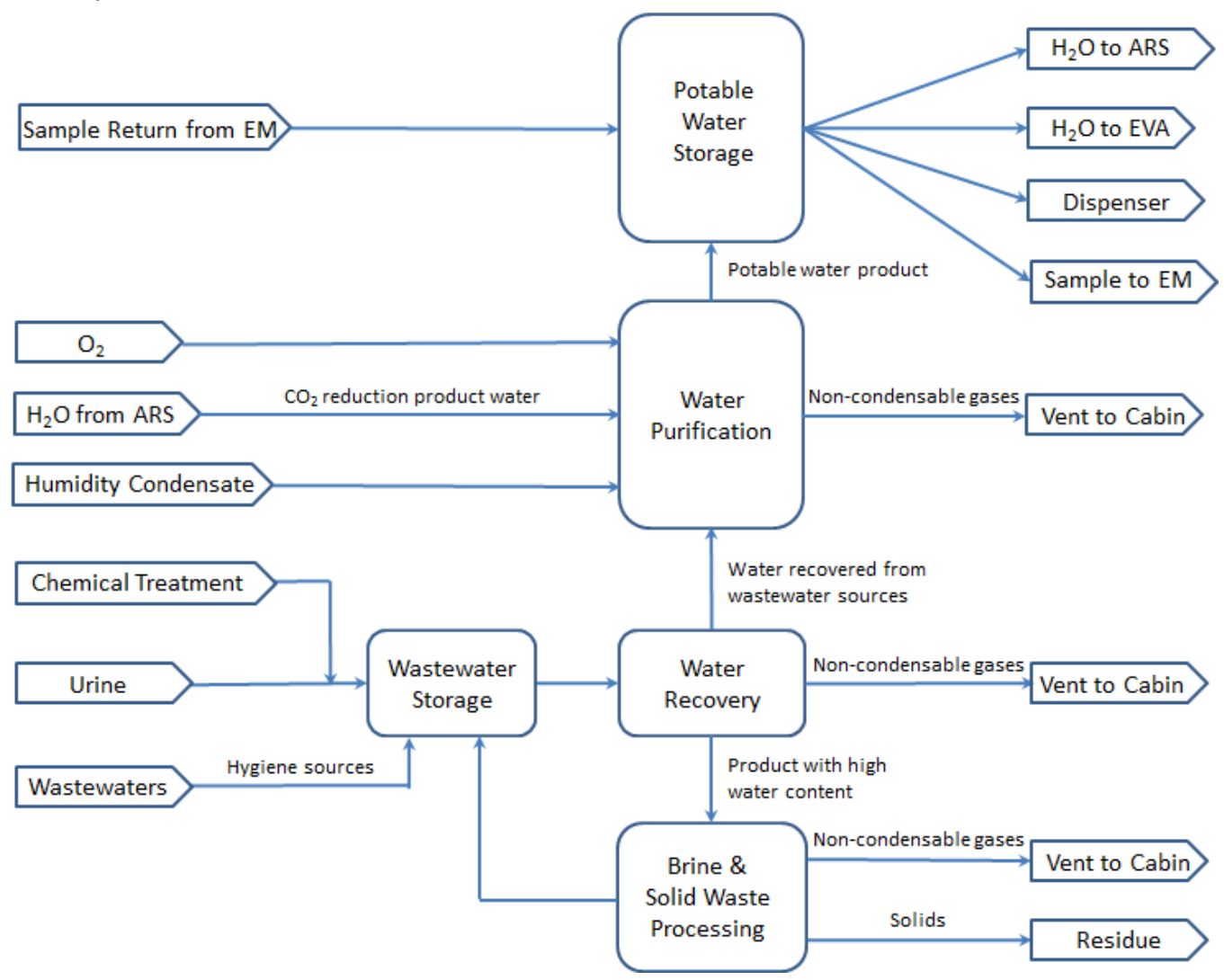

Figure 3. A simplified WRM subsystem block diagram for exploration missions. 


\section{B. WRM Subsystem Performance Guidance}

As depicted by Fig. 3, the WRM subsystem must manage the mission potable $\mathrm{H}_{2} \mathrm{O}$ supply; extract $\mathrm{H}_{2} \mathrm{O}$ from crewgenerated waste streams such as urine, feces, and hygiene wastes; and maintain functional interfaces with the AR and EM subsystems as well as support EVA operations. As such, the WRM subsystem serves a critical role in LSS resource recycling that reduces the total consumables that must be launched from Earth at the mission's beginning. The WRM subsystem must provide for an appropriate interface to enable pre-flight, in-flight, and post-flight $\mathrm{H}_{2} \mathrm{O}$ quality sampling. Since storing $\mathrm{O}_{2}$ in the form of $\mathrm{H}_{2} \mathrm{O}$ is a technical option, the WRM subsystem plays a crucial role in managing the mission's $\mathrm{O}_{2}$ resources. Relating to these roles, guidance pertaining to potable $\mathrm{H}_{2} \mathrm{O}$ quality, minimum $\mathrm{H}_{2} \mathrm{O}$ quantity, and waste quantity is found in NASA-STD-3001 and NASA/SP-2010-3407.

\section{Potable Water Quality}

Potable $\mathrm{H}_{2} \mathrm{O}$ quality consists of three areas - chemical contaminant concentration limits, microbial contaminant limits, and aesthetic limits. Chemical contaminants must be maintained below the spacecraft water exposure guidelines (SWEG) documented in Spacecraft Water Exposure Guidelines for Selected Waterborne Contaminants (JSC 63414). For instances where a contaminant has no documented SWEG, the U.S. Environmental Protection Agency (U.S. EPA) the maximum contaminant levels for safe drinking water apply for WRM design (http://www.epa.gov/safewater/contaminants). ${ }^{43}$ Total organic carbon (TOC), a useful parameter for WRM subsystem process control, must be maintained $<3 \mathrm{mg} / \mathrm{L}$ in the potable $\mathrm{H}_{2} \mathrm{O}$ product. If iodine is used as an antimicrobial additive, the concentration in the potable water must not exceed $0.2 \mathrm{mg} / \mathrm{L}$.

Microbial contamination guidance addresses bacteria, coliform bacteria, fungi, and parasitic protozoa. Bacteria must be maintained $<50$ bacterial $\mathrm{CFU} / \mathrm{mL}$ while both the coliform bacteria and fungal count must be undetectable for each 100 $\mathrm{mL}$ of potable water. The parasitic protozoa level must be maintained at zero. ${ }^{44}$

Aesthetic limits, summarized by Table 3, must be maintained for taste, odor, turbidity, color, dissolved gas, and $\mathrm{pH} .{ }^{45}$

2. Wastewater Contaminant Load

The contaminant load in the chemically and microbiologically stabilized wastewater streams must be determined. This load can be specific to the wastewater source and the chemical treatment employed. Efforts to characterize these wastewater streams must be conducted and sufficient data acquired to afford a good statistical representation that can be used for design. The contaminant load for each wastewater source used for the WRM subsystem design should represent the $95 \%$ confidence interval upper bound for the datasets acquired during wastewater stream characterization.

Humidity condensate samples collected aboard the ISS and returned to the ground for analysis afford an excellent dataset on the expected contaminant load for this wastewater source. Table 4 summarizes the analysis results from fifty-four humidity condensate samples returned from the ISS over the fifteen year period between March 2001 and February 2016. For
Table 3. Potable water aesthetic limits.

\begin{tabular}{|l|c|}
\hline \multicolumn{1}{|c|}{ PARAMETER } & LIMIT \\
\hline Taste & $3 \mathrm{TTN}$ \\
\hline Odor & $3 \mathrm{TON}$ \\
\hline Turbidity & $1 \mathrm{NTU}$ \\
\hline Color, True & $15 \mathrm{PCU}$ \\
\hline Free and Dissolved Gas & $0.1 \%$ \\
\hline Acidity $(\mathrm{pH})$ & $4.5-9.0$ \\
\hline
\end{tabular}

Table 4. ISS humidity condensate loading.

\begin{tabular}{|c|c|c|}
\hline \multirow[b]{2}{*}{ PARAMETER } & \multicolumn{2}{|c|}{ CONCENTRATION } \\
\hline & $\begin{array}{c}\text { Average } \\
(\mathrm{mg} / \mathrm{L})\end{array}$ & $\begin{array}{c}\text { Std. Dev. } \\
\text { (mg/L) }\end{array}$ \\
\hline TOC & 171.45 & 97.12 \\
\hline TIC & 33.76 & 13.83 \\
\hline Bromide & 1.07 & 0.68 \\
\hline Chloride & 0.48 & 0.35 \\
\hline Fluoride & 1.64 & 3.29 \\
\hline Nitrate as $\mathrm{N}$ & 0.19 & 0.06 \\
\hline Phosphate & 0.40 & 0.16 \\
\hline Sulfate & 1.10 & 0.58 \\
\hline Ammonia as $\mathrm{N}$ & 37.54 & 15.68 \\
\hline Calcium & 0.32 & 0.26 \\
\hline Potassium & 1.28 & 2.26 \\
\hline Manganese & 0.21 & 0.58 \\
\hline Nickel & 2.49 & 3.52 \\
\hline Silver & 0.14 & 0.37 \\
\hline Zinc & 19.61 & 18.60 \\
\hline 1-Butanol & 1.18 & 0.66 \\
\hline Ethanol & 54.36 & 50.48 \\
\hline Methanol & 4.77 & 1.67 \\
\hline 1-Propanol & 1.00 & 1.07 \\
\hline 2-Propanol & 1.29 & 2.16 \\
\hline 1,2-Ethanediol & 7.00 & 6.21 \\
\hline 1,2-Propanediol & 31.06 & 28.07 \\
\hline Dimethylsilanediol & 41.19 & 21.88 \\
\hline Trimethylsilanol & 0.40 & 0.19 \\
\hline Benzyl alcohol & 20.45 & 20.21 \\
\hline Acetaldehyde & 0.31 & 0.40 \\
\hline Formaldehyde & 1.45 & 2.84 \\
\hline Acetone & 1.46 & 0.87 \\
\hline Dibutylphthalate & 0.18 & 0.11 \\
\hline Diethylphthalate & 1.11 & 0.31 \\
\hline Acetate & 60.58 & 62.09 \\
\hline Formate & 13.96 & 13.16 \\
\hline Lactate & 56.06 & 81.08 \\
\hline Propionate & 2.52 & 2.28 \\
\hline Urea & 3.60 & 3.69 \\
\hline Caprolactam & 7.57 & 8.33 \\
\hline
\end{tabular}


these samples, the $\mathrm{pH}$ averaged 7.3 with a standard deviation of 0.42 . The TOC averaged $171.45 \mathrm{mg} / \mathrm{L}$ with a standard deviation of $97.12 \mathrm{mg} / \mathrm{L}$ while the total inorganic carbon (TIC) average $33.76 \mathrm{mg} / \mathrm{L}$ with a standard deviation of $13.83 \mathrm{mg} / \mathrm{L}$. Both TOC and TIC are key indicators of the overall contaminant loading. In addition to TOC and TIC, Table 4 provides concentration information for anions, cations, metals, and specific organic contaminants observed in humidity condensate. For design purposes, using a concentration representative of the $95 \%$ confidence interval upper boundary is appropriate.

3. Minimum Water Quantity

The WRM subsystem must manage a minimum quantity of water each mission day for the life of the mission to accommodate crew health and hygiene as well as support EVA and AR subsystem operations. ${ }^{46,}{ }^{47}$ Table 5 summarizes the primary uses and minimum quantities that must be supported. For an LSS AR subsystem architecture that uses $\mathrm{H}_{2} \mathrm{O}$ electrolysis to satisfy the crew's oxygen demand in Table 1, up to an additional $1.03 \mathrm{~kg} / \mathrm{CM}$-day is necessary. The AR subsystem's water demand on the WRM subsystem can be minimized by employing a highly effective $\mathrm{CO}_{2}$ reduction process.

For long duration missions, the potable $\mathrm{H}_{2} \mathrm{O}$ dispenser must provide by cold and hot water. The maximum cold water temperature is $15.6{ }^{\circ} \mathrm{C}$ and the temperature range for the hot water is 68.3 to $79.4{ }^{\circ} \mathrm{C}$. The hot water is used for food hydration and hot drinks. The temperature for the water used for personal hygiene must be dispensed at a temperature between

Table 5. Minimum water quantities by use.

\begin{tabular}{|l|c|}
\hline \multicolumn{1}{|c|}{ WATER USE } & QUANTITY \\
\hline Drinking & $2 \mathrm{~kg} / \mathrm{CM}$-day \\
\hline Food hydration & $0.5 \mathrm{~kg} / \mathrm{CM}$-day \\
\hline Personal hygiene & $0.4 \mathrm{~kg} / \mathrm{CM}$-day \\
\hline Medical support & $5 \mathrm{~kg}+0.5 \mathrm{~kg} / \mathrm{CM}$ \\
\hline EVA support & $0.24 \mathrm{~kg} / \mathrm{h}$ of EVA \\
\hline Earth entry fluid loading & $1 \mathrm{~kg} / \mathrm{CM}$ \\
\hline Post-landing support & $4.5 \mathrm{~kg} / \mathrm{CM}$ \\
\hline
\end{tabular}
$29.4{ }^{\circ} \mathrm{C}$ and $46.1^{\circ} \mathrm{C}$.

4. Water Recovery from Trash, Human Waste, and Byproducts

Recovering $\mathrm{H}_{2} \mathrm{O}$ from trash, human waste, and byproducts produced by the LSS is vital for minimizing the total stored $\mathrm{H}_{2} \mathrm{O}$ necessary for long duration exploration missions. The WRM's processing rates must therefore accommodate the waste production rates and the subsequent $\mathrm{H}_{2} \mathrm{O}$ recovery from these waste streams.

Trash produced aboard the ISS typically has $\sim 30 \% \mathrm{H}_{2} \mathrm{O}$ content by mass. ${ }^{48}$ Most of this $\mathrm{H}_{2} \mathrm{O}$ comes from food and drink residues and hygiene wipes. Processing the trash to reclaim this $\mathrm{H}_{2} \mathrm{O}$ can help reduce the total stored $\mathrm{H}_{2} \mathrm{O}$ resource requirement for an exploration mission.

The total amount of urine for a mission is estimated using the equation, $V_{u}=3+2 t$, where $V_{u}$ is the urine volume in liters and $t$ is the mission length in days. The urine collection capacity must accommodate a daily single CM production rate of up to $1 \mathrm{~L}$ urine/event and 6 events/CM-day. This collection rate provides for a $20 \%$ functional margin over the equation used for estimating a mission's total urine volume. ${ }^{49}$

Processing feces to recover $\mathrm{H}_{2} \mathrm{O}$ must accommodate production up to $150 \mathrm{~g} /$ event for 2 events/CM-day. ${ }^{50}$ This is an important source for $\mathrm{H}_{2} \mathrm{O}$ reclamation for long duration missions since feces typically contain $\sim 75 \%$ water by weight. $^{51}$

Water may also be reclaimed from byproducts produced by the WRM subsystem itself. Reclaiming $\mathrm{H}_{2} \mathrm{O}$ from urine produces a highly concentrated aqueous brine. Extracting $\mathrm{H}_{2} \mathrm{O}$ from this WRM subsystem-produced byproduct can further reduce an exploration mission's total stored $\mathrm{H}_{2} \mathrm{O}$ requirements.

\section{Environmental Monitoring}

The EM subsystem provides data to the Environmental Health System (EHS) as well as aids the LSS by ensuring that the WRM and AR subsystems are functioning properly to provide potable water and a breathable cabin atmosphere. Functional requirement guidance from NASA-STD-3001, NASA/SP-2010-3407, and relevant supporting documentation is presented.

\section{A. EM Subsystem Exploration Architecture Overview}

Figure 4 illustrates four primary monitoring focal areas $-\mathrm{H}_{2} \mathrm{O}$ quality, atmospheric quality, microbial load, and contamination contingency events. Water quality and atmospheric quality monitoring provide continuing verification that the WRM and AR subsystems are functioning properly in addition to providing the EHS with data to evaluate risk presented by the crew's exposure to environmental contaminants. Data from the EM subsystem may be used to provide control inputs to assist in efficiently managing the LSS and its resources through autonomous control algorithms. These data are also used by the Caution and Warning System (CWS) to alert the crew to conditions that 
are approaching or exceeding specification limits. The following provides a brief overview of each EM subsystem monitoring focal area.

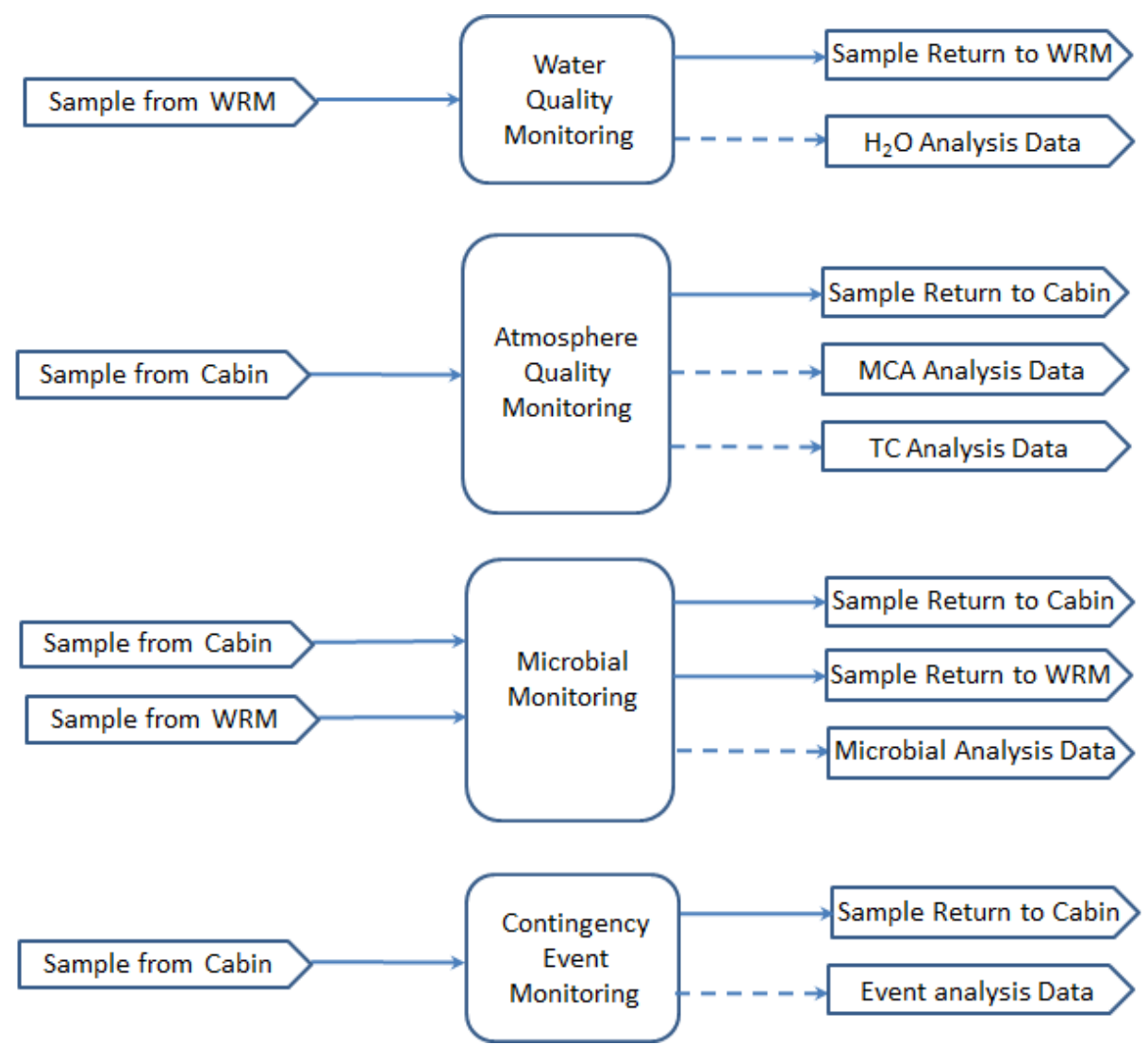

Figure 4. A simplified EM subsystem block diagram for exploration missions. Data from the EM subsystem are used by the EHS, LSS, and CWS.

\section{Atmospheric Quality Monitoring}

Cabin atmospheric quality monitoring encompasses both major and trace constituent targets listed by Table $6^{52}$ as well as suspended particulate matter. Combined with cabin temperature, humidity, and pressure monitoring data, the atmospheric concentration data for major and trace constituents and suspended particulate matter are instrumental in maintaining the cabin environment within a safe, comfortable range. These data also provide the information necessary to the EHS for assessing crew health risks due to exposures to environmental contaminants. Most of the trace constituents listed in Table 6 are common to the trace contaminant control design load presented by Table 2 which allows for continuous active trace contaminant control functional verification during the mission. The trace constituent targets presented by Table 6 are presently those that are of most interest to the LSS and environmental health technical disciplines. As exploration mission definition continues, it is anticipated that the trace constituent target compound list will experience some modification.

\section{Water Quality Monitoring}

Water quality monitoring provides the information necessary to assess and characterize the quality of $\mathrm{H}_{2} \mathrm{O}$ sources and continually verifies that the $\mathrm{H}_{2} \mathrm{O}$ recovery and purification systems produce a product that meets potable $\mathrm{H}_{2} \mathrm{O}$ requirements. Water quality monitoring also provides data to the EHS to be used for contaminant exposure risk assessment based on the SWEGs. Specific $\mathrm{H}_{2} \mathrm{O}$ quality monitoring functions include the following. Water quality monitoring targets include but are not limited to the parameters listed in Table 4. The EM subsystem must be able to accept and process a $500 \mathrm{~mL}$ sample from the WRM.

3. Microbial Monitoring

Microbial monitoring provides the information necessary to assess airborne and waterborne bacterial and fungal contamination levels as well as surface contamination to address issues related to infectious disease and microbial ecology aboard spacecraft. In general the microbial monitoring must identify and enumerate microbes in air, $\mathrm{H}_{2} \mathrm{O}$, and surface samples. 


\section{Contingency Event Monitoring}

Equipment overheating events and system fluid leaks comprise the targeted contingency events listed in Table 6. Primary combustion products include carbon monoxide (CO), hydrogen cyanide ( $\mathrm{HCN})$, hydrogen chloride $(\mathrm{HCl})$, and hydrogen fluoride $(\mathrm{HF})$. Combustion product monitoring is used in tandem with smoke detection to alert the crew of an event and to aid in determining its location.

Targeted chemical monitoring addresses leaks from vehicle system and experimental payload equipment that may present acute health hazards to the crew or degrade the LSS function. Chemicals used as working fluids in thermal control systems, such as ammonia $\left(\mathrm{NH}_{3}\right)$, 1,2-propanediol, and perfluorinated compounds are examples. Monitoring propellants such as hydrazine which may enter the cabin environment during EVA or upon returning to Earth serves to alert the crew to an acutely dangerous situations.

In general, chemicals used aboard crewed spacecraft must not exceed toxic hazard level 3 as defined by Guidelines for Assessing the Toxic Hazard of Spacecraft Chemicals and Test Materials (JSC 26895) and be compatible with the LSS according to analysis conducted according to Guidelines for the Assessment of Chemicals and Materials for Impacts to Environmental Control and Life Support Systems and Habitable Volumes of Crewed Spacecraft (JSC 66869). Bulk chemical use aboard the vehicle that does not comply with these guidelines must demonstrate a containment design for minimum risk relative to their release into the cabin environment. It is highly recommended that a suitable replacement be used in instances where a chemical is rated above toxic hazard level 3.

\section{B. EM Subsystem Requirements}

The EM subsystem's functional equipment provide important data relative to crew health and LSS health. These data must be suitable for conducting temporal trend analysis. ${ }^{53}$ The data must be displayed real time as well as recorded. Specifically data on cabin pressure, humidity, temperature, $\mathrm{O}_{2}$ partial pressure, and $\mathrm{CO}_{2}$ partial pressure must be displayed and recorded for all mission classes of any duration. ${ }^{54}$ The EM subsystem must also work intimately with the C\&WS to alert the crew when an off-nominal situation arises. ${ }^{55}$

For mission durations exceeding 30 days, the EM subsystem must also continuously monitor trace atmospheric constituents and alert the crew of conditions that are approaching or exceeding the SMAC levels. Continuous combustion product and chemical leak event monitoring must be provided and the crew must be alerted of a contamination event in a timely manner such that they have time to take appropriate action.

Monitoring performance parameters pertaining to detection ranges, qualitative accuracy, quantitative accuracy, precision, and response time are derived from EHS, LSS, and C\&WS performance needs.

\section{LSS Interfaces and Resource Allocation}

Since the exploration mission planning is in pre-Phase A to early Phase A, details on functional interfaces and resource allocations are not well defined. However, some early guidance is available. Functional interfaces for an

11

American Institute of Aeronautics and Astronautics 
exploration LSS architecture are discussed by Ref. 17 for electrical power, avionics and software, thermal control, and structural elements.

Of most interest herein are the electrical power and avionics elements. The Mars DRA5 uses a legacy 120 VDC source. While the Mars DRA5 total power estimate is for $22 \mathrm{~kW}$, an LSS allocation is not yet specified. ${ }^{56}$ Yet, any LSS architecture should strive to minimize its power demands within the design performance envelope. Developmental efforts for avionics and software are described by Refs. 57 through 60. The exploration architecture for avionics is based on an Ethernet "backbone" suitable for accommodating large data volumes. Commercial-off-the-shelf hardware and software products are also being evaluated. The exploration LSS development efforts are working closely with avionics and software developers toward early adoption of their recommended network, software, and hardware features.

Structural elements and packaging for the exploration LSS must enable easy in-flight maintenance. Because future crewed missions cannot employ the Earth-based logistics model used by the ISS Program, an in-flight logistics model must be developed. This logistics approach is highly dependent upon easy equipment access for in-flight maintenance and a minimal spare part mass and volume. As the exploration LSS design matures, a great deal of attention must be given to maintainability and spare part logistics.

Resource allocations for mass, electrical power, volume, thermal control, data rates, and many other technical areas are not yet specified. The Mars DRA5 assessed a deep space habitat for a 1000-day, 6-CM mission that allocates $11803 \mathrm{~kg}$ for the LSS. Within this total, the AR subsystem is allocated $1848 \mathrm{~kg}$ and the WRM $5971 \mathrm{~kg}$. An aggressive reduced mass strategy allocates $9114 \mathrm{~kg}$ to the LSS with the AR subsystem allocated $1651 \mathrm{~kg}$ and the WRM allocated $3687 \mathrm{~kg}$. The LSS consumables are allocated $1373 \mathrm{~kg}$ under the primary strategy and $1345 \mathrm{~kg}$ under the aggressive strategy. ${ }^{61}$

In total, the exploration LSS must address exploration figures of merit that include safety, mission success, effectiveness, and affordability. ${ }^{62}$ To achieve these figures of merit, the exploration LSS design must address performance elements pertaining to maintainability, robustness, scalability. As such, the exploration LSS must be easily and economically maintained without an Earth-based logistics framework, perform in a stable and consistent manner across variable mission flight environments, and accommodate multiple mission objectives and vehicle platforms.

\section{Guidance from ISS Life Support System Operations and Future Work}

Operating the LSS aboard the ISS offers insight that augments general requirement guidance. Insight from the documents listed in the appendix shows that exploration LSS development can benefit by considering how the cabin environment can interact with the system's process technologies, developing software early in the development cycle to support integrated hardware-software testing, and achieving an autonomous EM capability.

Minor contaminants that can emanate from highly diverse, low offgassing sources, such as formaldehyde and volatile methyl siloxanes, can become a significant challenge when large quantities of those sources are introduced into the habitable environment. Such contaminants can arise from materials used in the vehicle's construction as in the case of formaldehyde or a combination of materials and personal care products as in the case of volatile methyl siloxanes. Challenges can also exist from contaminant decomposition and reaction. Examples include volatile methyl siloxane hydrolysis to form dimethylsilanediol and granular lithium hydroxide ( $\mathrm{LiOH}$ ) conversion to lithium chloride $(\mathrm{LiCl})$ on reaction with $\mathrm{HCl}$ produced in a LSS trace contaminant control process. The highly water soluble dimethylsilanediol presents a significant process economics challenge for the WRM subsystem. The reaction of Li$\mathrm{OH}$ with $\mathrm{HCl}$ results in $\mathrm{LiOH}$ granule size reduction that leads to rising pressure drop across the packed bed.

Cabin major and trace constituents can also diffuse through elastomeric flex hose materials. For example, $\mathrm{CO}_{2}$ permeation through Teflon ${ }^{\mathrm{TM}}$ hose used in the ISS internal thermal control system resulted in changes in the fluid's chemistry over time. This change in fluid chemistry resulted in increased corrosion rates in some thermal control system components and increased the fluid's susceptibility to microbial contamination. Moisture permeation through hose materials can impact processes that must remain dry such as when feeding $\mathrm{CO}_{2}$ concentrated by the $\mathrm{CO}_{2} \mathrm{re}-$ moval process to downstream conditioning and resource recovery equipment. Oxygen and moisture permeation can also be an issue for some thermal working fluids in which $\mathrm{O}_{2}$ and moisture readily dissolve. Understanding these reactive and gas permeation mechanisms as well as selecting chemicals and process fluids that are compatible with both the LSS and the cabin environment can assist in selecting process technologies and fluids that are integral to a robust LSS design.

Software development typically lags hardware development which can contribute to late integrated hardwaresoftware testing. Many challenges have arisen aboard the ISS due to hardware-software integration issues. Beginning the software development concurrently with hardware development and conducting integrated testing early and often may reduce the number, frequency, and severity of hardware-software integration issues. 
The environmental monitoring strategy used aboard the ISS relies heavily on collecting samples that are returned to ground-based laboratories for analysis. The elapsed time between sample collection and reporting analysis results can easily exceed six months. More near real-time methods are being explored and demonstrated aboard the ISS, yet sample analysis by a ground-based laboratory remains the standard for comparison. Developing an autonomous environmental monitoring capability that requires little crew intervention or in-flight laboratory resources such as reagents and workbench space is essential to future mission success. Returning samples to a ground-based laboratory is not an option for exploration missions and the LSS must be better integrated with the EM subsystem to ensure the crew's health, safety, and performance are preserved.

Beyond process technology development for the exploration LSS, future work is necessary in several areas that are important for sizing the LSS components and developing an in-flight maintainable physical layout. First, while an airborne lunar surface dust standard has been developed and provides an excellent starting position for exploration mission particulate filtration design, Martian surface dust has different properties that may impact human health differently. These properties include the chromium, perchlorate, and manganese content reported in Martian surface dust. An airborne Martian dust standard may be close to the standard set for lunar dust; however, more assessment and scientific study is necessary to arrive at a recommendation. Second, as the exploration vehicle and habitat platforms become better defined, more work can be accomplished relating to LSS hardware component fit and form. While LSS technology maturation efforts have a near-term focus on performance maturation with the goal of realizing a minimal mass and volume package, the details on hardware component fit and form depend on a well-defined size envelope for the LSS hardware. The hardware component fit and form will also be instrumental in developing an in-flight maintainable physical hardware layout. Third, the LSS must accommodate the environments encountered during all exploration mission phases. Defining these environments is essential to addressing various LSS design robustness aspects. Finally, accommodating plants in the exploration vehicle cabin must be evaluated. While plants can supplement the food supply, provide aesthetic benefits, and supplement the $\mathrm{LSS}_{2}$ supply function, they have resource demands that may impact LSS functional margins. For example, plants can contribute significantly to the humidity and $\mathrm{CO}_{2}$ loads through transpiration and respiration, particularly if the respiration and photosynthesis processes are not fully balanced. The exploration LSS design must account for these loads in addition to supplying water to support plant growth.

\section{Conclusion}

A vision for crewed exploration that builds toward exploration Mars is guiding NASA's technical development efforts to lead humanity's pioneering spirit into the solar system. Mission design reference architectures, exploration goals, and technology needs assessments have been conducted and are updated as the knowledge base grows. The Mars DRA5 serves as the greatest challenge for the engineers and scientists who are developing the next generation LSS that will enable this adventure. Guiding requirements for the exploration LSS are readily obtained from the Mars DRA5 documentation, NASA-STD-3001, NASA/SP-2010-3407, and experience gained from LSS flight operations aboard the ISS. This documentation provides excellent guidance for the technological development efforts that are necessary to realize the space exploration vision in which the LSS employs an in-space logistics framework and exceeds expectations for safety, mission success, effectiveness, and affordability.

\section{Appendix}

The following documentation supplements the requirements found in the NASA Space Flight Human System Standard (NASA-STD-3001) and the Human Integration Design Handbook (NASA/SP-2010-3407) and provides background on technology performance and lessons learned aboard the ISS.

\section{General Design and Standards Supplemental Guidance}

Parker, J.F. and West, V.R., Bioastronautics Data Book, NASA SP-3006, 1973.

Wieland, P.O., Designing for Human Presence in Space, NASA RP-1324, 1994.

Wieland, P.O., Living Together in Space: The Design and Operation of the Life Support Systems on the International Space Station, NASA/TM-1998-206956, Vol. I, January 1998.

Perry, J.L., Elements of Spacecraft Cabin Air Quality Control Design, NASA/TP-1998-207978, May 1998.

James, J.T., "Airborne Dust in Space Vehicles and Habitats," SAE 2006-01-2152, SAE 36 ${ }^{\text {th }}$ International Conference on Environmental Systems, Norfolk, Virginia, 2006.

James, J.T., "The Headache of Carbon Dioxide Exposures," SAE 2007-01-3218, SAE 37th International Conference on Environmental Systems, Chicago, Illinois, 2007.

James, J.T., "Air Quality Standards for Space Vehicles and Habitats," SAE 2008-01-2125, SAE 38 ${ }^{\text {th }}$ International Conference on Environmental Systems, San Francisco, California, 2008. 
McCoy, J.T. and James, J.T., "Water Quality Standards for Space Vehicles and Habitats," SAE 2008-01-2196, SAE 38 ${ }^{\text {th }}$ International Conference on Environmental Systems, San Francisco, California, 2008.

James, J.T., "A History of Space Toxicology Mishaps: Lessons Learned and Risk Management," SAE 2009-01-2591, SAE $39^{\text {th }}$ International Conference on Environmental Systems, Savannah, Georgia, 2009.

Perry, J.L., "A Design Basis for Spacecraft Cabin Trace Contaminant Control," SAE 2009-01-2592, SAE 39 $9^{\text {th }}$ International Conference on Environmental Systems, Savannah, Georgia, 2009.

Safety Design for Space Systems, G.E. Musgrave, A.M. Larson, and T. Sgobba, Editors, Elsevier, Ltd., 2009, pp. 185-224, 359-374, 607-660.

James, J.T. and Zalesak, S.M., "Surprising Effects of $\mathrm{CO}_{2}$ Exposure on Decision Making," AIAA 2013-3463, AIAA 43 ${ }^{\text {rd }}$ International Conference on Environmental Systems, Vail, Colorado, 2013.

Macatangay, A.V., "An Assessment of Environmental Health Needs," AIAA 2013-3465, AIAA 43 ${ }^{\text {rd }}$ International Conference on Environmental Systems, Vail, Colorado, 2013.

Life Support Baseline Values and Assumptions Document, NASA/TP-2015-218570, March 2015.

Perry, J.L., and Kayatin, M.J., Trace Contaminant Control Design Considerations for Enabling Exploration Missions, ICES 2015-108, 45 ${ }^{\text {th }}$ International Conference on Environmental Systems, Bellevue, Washington, 2015.

Exploration Systems Development Medical Operations Requirements Document, ESD 10024, NASA, October 2015.

Human Systems Integration Practitioner's Guide, NASA/SP-2015-3709, November 2015.

Agui, J., Vijayakumar, R., and Perry, J., "Particulate Filtration Design Considerations for Crewed Spacecraft Life Support Systems," ICES-2016-93, 46 $6^{\text {th }}$ International Conference on Environmental Systems, Vienna, Austria, 2016.

Perry, J.L., Agui, J.H., and Vijayakumar, R., "Submicron and Nanoparticulate Matter Removal by HEPA-Rated Media Filters and Packed Beds of Granular Materials," NASA/TM-2016-218224, NASA/Marshall Space Flight Center, Huntsville, Alabama, May 2016.

\section{Atmosphere Revitalization}

Cloud, D. and Kundrotas, R.E., "Development Status and Safety Features of ISS Oxygen Generation and Water Processor Assemblies," SAE 2000-01-2349, SAE 30 ${ }^{\text {th }}$ International Conference on Environmental Systems and $7^{\text {th }}$ European Symposium on Space Environmental Control Systems, Toulouse, France, 2000.

Gatzuras, J., and Gervais, T., "The Design and Development of Pumps for the ISS Oxygen Generation and Water Processor Assemblies," SAE 2000-01-2350, SAE 30 ${ }^{\text {th }}$ International Conference on Environmental Systems and $7^{\text {th }}$ European Symposium on Space Environmental Control Systems, Toulouse, France, 2000.

Graf, J., Perry, J.L., Wright, J.D., and Bahr, J.A., "Process Upsets Involving Trace Contaminant Control Systems," SAE 2000-01-2429, SAE 30 International Conference on Environmental Systems and $7^{\text {th }}$ European Symposium on Space Environmental Control Systems, Toulouse, France, 2000.

Perry, J.L., El-Lessy, H.N., Cole, H.E., Cramblit, E.L., Manuel, S., and Tucker, C.D., "Post-Flight Sampling and Loading Characterization of Trace Contaminant Control Subassembly Charcoal," SAE 2003-01-2487, SAE 33 rd International Conference on Environmental Systems, Vancouver, British Columbia, Canada, 2003.

Perry, J.L., von Jouanne, R.G., and Turner, E.H., "International Space Station Bacteria Filter Element Post-flight Testing and Service Life Predictions," SAE 2003-01-2490, SAE 33 ${ }^{\text {rd }}$ International Conference on Environmental Systems, Vancouver, British Columbia, Canada, 2003.

Perry, J.L. and Peterson, B.V., "Cabin Air Quality Dynamics On Board the International Space Station," SAE 2003-01-2650, SAE 33 ${ }^{\text {rd }}$ International Conference on Environmental Systems, Vancouver, British Columbia, Canada, 2003.

Samplatsky, D., "Development Status of the ISS Oxygen Generation and Water Processor Assemblies, SAE 2003-01-2691, SAE $33^{\text {rd }}$ International Conference on Environmental Systems, Vancouver, British Columbia, Canada, 2003.

Philistine, C., "Water Use for Oxygen Generation," SAE 2004-01-2449, SAE $34^{\text {th }}$ International Conference on Environmental Systems, Colorado Springs, Colorado, 2004.

Reysa, R.P., "International Space Station Carbon Dioxide Removal Assembly On-Orbit Performance," SAE 2004-01-2543, SAE 34 ${ }^{\text {th }}$ International Conference on Environmental Systems, Colorado Springs, Colorado, 2004.

El Sherif, D., "International Space Station Carbon Dioxide Removal Assembly Troubleshooting and Evaluation," SAE 200401-2548, SAE 34 ${ }^{\text {th }}$ International Conference on Environmental Systems, Colorado Springs, Colorado, 2004.

Knox, J.C., Campbell, M.L., Murdoch, K.E., Jeng, F.F., and Miller, L.A., "Integrated Test and Evaluation of a 4-Bed Molecular Sieve Carbon Dioxide Removal System, Mechanical Compressor Engineering Development Unit, and Sabatier Engineering Development Unit," SAE 2005-01-2864, SAE 35 th International Conference on Environmental Systems and $8^{\text {th }}$ European Symposium on Space Environmental Control Systems, Rome, Italy, 2005.

El Sherif, D. and Knox, J.C., "International Space Station Carbon Dioxide Removal Assembly Concepts and Advancements," SAE 2005-01-2892, SAE 35 ${ }^{\text {th }}$ International Conference on Environmental Systems and $8^{\text {th }}$ European Symposium on Space Environmental Control Systems, Rome, Italy, 2005.

Perry, J.L., "Formaldehyde Concentration Dynamics of the International Space Station Cabin Atmosphere," SAE 2005-013091, SAE 35 th International Conference on Environmental Systems and $8^{\text {th }}$ European Symposium on Space Environmental Control Systems, Rome, Italy, 2005.

Watter, P. and Schaezler, R., "International Space Station Metabolic Oxygen Consumption for Expedition 12," SAE 200601-2090, SAE $36^{\text {th }}$ International Conference on Environmental Systems, Norfolk, Virginia, 2006. 
Perry, J.L. and Arnold, W.A., "An Environmental Impact Assessment of Perfluorocarbon Thermal Working Fluid Use Aboard Crewed Spacecraft," SAE 2006-01-2218, SAE $36^{\text {th }}$ International Conference on Environmental Systems, Norfolk, Virginia, 2006.

Erickson, R.J., Howe, J., Kulp, G.W., and van Keuren, S.P., "International Space Station United States Orbital Segment Oxygen Generation System On-Orbit Operational Experience," SAE 2008-01-1962, SAE 38 ${ }^{\text {th }}$ International Conference on Environmental Systems, San Francisco, California, 2008.

Macatangay, A., Perry, J., Belcher, P., and Johnson, S., "Status of the International Space Station Trace Contaminant Control System," SAE 2009-01-2353, SAE 39 ${ }^{\text {th }}$ International Conference on Environmental Systems, Savannah, Georgia, 2009.

Perry, J.L. and Aguilera, T., "Root Cause Assessment of Pressure Drop Rise of a Packed Bed of Lithium Hydroxide in the International Space Station Trace Contaminant Control System," SAE 2009-01-2433, SAE 39 ${ }^{\text {th }}$ International Conference on Environmental Systems, Savannah, Georgia, 2009.

Samplatsky, D., Grohs, K., Edeen, M., and Crusan, J., "Development and Integration of the Flight Sabatier Assembly on the ISS," AIAA-2011-5151, AIAA 41 ${ }^{\text {st }}$ International Conference on Environmental Systems, Portland, Oregon, 2011.

Perry, J. and Coston, J., "Analysis of Particulate and Fiber Debris Samples Returned from the International Space Station," ICES-2014-166, 44 ${ }^{\text {th }}$ International Conference on Environmental Systems, Tucson, Arizona, 2014.

Meyer, M., "ISS Ambient Air Quality: Updated Inventory of Known Aerosol Sources," ICES-2014-199, 44 ${ }^{\text {th }}$ International Conference on Environmental Systems, Tucson, Arizona, 2014.

Carter, D., Wilson, M., Bowman, E., Perry, J., Kayatin, M., Steele, J., Rector, T., Gentry, G., and Monje, O., "Process Development for Removal of Siloxanes from ISS Atmosphere," ICES-2015-74, 45 ${ }^{\text {th }}$ International Conference on Environmental Systems, Bellevue, Washington, 2015.

Gazda, D., McCoy, T., Limero, T., Perry, J., and Carter, D., “Assessment of Ethanol Trend on ISS,” ICES-2016-12, 46 ${ }^{\text {th }}$ International Conference on Environmental Systems, Vienna, Austria, 2016.

Carter, D., Kayatin, M., Wilson, M., Perry, J., Rector, T., Agui, J., Gentry, G., Bowman, E., and Greene, R., "Design and Delivery of a Filter for Removal of Siloxanes from the ISS Atmosphere," ICES-2016-15, $46^{\text {th }}$ International Conference on Environmental Systems, Vienna, Austria, 2016.

Perry, J.L. and Kayatin, M.J., "The Fate of Trace Contaminants in a Crewed Spacecraft Cabin Environment," ICES-2016-91, $46^{\text {th }}$ International Conference on Environmental Systems, Vienna, Austria, 2016.

\section{Water Recovery and Management}

Holder, D.W., O’Connor, E.W., Zagaya, J., and Murdoch, K.E., "Investigation into the Performance of Membrane Separator Technologies used in the International Space Station Regenerative Life Support Systems: Results and Lessons Learned," SAE 2001-01-2354, SAE 31 ${ }^{\text {st }}$ International Conference on Environmental Systems, Orlando, Florida, 2001.

Holder, D.W., "Development Status of the International Space Station Urine Processor Assembly," SAE 2003-01-2690, SAE $33^{\text {rd }}$ International Conference on Environmental Systems, Vancouver, British Columbia, Canada, 2003.

Hutchens, C. and Graves, R., "Results of the Vapor Compression Distillation Flight Experiment," SAE 2004-01-2450, SAE $34^{\text {th }}$ International Conference on Environmental Systems, Colorado Springs, Colorado, 2004.

Carter, L, Tatara, J., O’Connor, E., Bedard, J.E., and Mason, R., "Performance Assessment of ISS Water Processor Assembly Reactor," SAE 2004-01-2451, SAE 34 ${ }^{\text {th }}$ International Conference on Environmental Systems, Colorado Springs, Colorado, 2004.

Carter, D.L., Tabb, D.R., Tatara, J., and Mason, R.K., "Performance Qualification Test of the ISS Water Processor Assembly Expendables," SAE 2005-01-2837, SAE 35 th International Conference on Environmental Systems and $8^{\text {th }}$ European Symposium on Space Environmental Control Systems, Rome, Italy, 2005.

Straub, J.E., Plumlee, D.K., and Schultz, J.R., "Chemical Analysis of ISS Potable Water from Expeditions 8 and 9," SAE 2005-01-2885, SAE 35 $5^{\text {th }}$ International Conference on Environmental Systems and $8^{\text {th }}$ European Symposium on Space Environmental Control Systems, Rome, Italy, 2005.

Bruce, R.J., Ott, C.M., Skuratov, V.M., and Pierson, D.L., "Microbial Surveillance of Potable Water Sources of the International Space Station," SAE 2005-01-2886, SAE 35 th International Conference on Environmental Systems and $8^{\text {th }}$ European Symposium on Space Environmental Control Systems, Rome, Italy, 2005.

Schutz, J.R., Plumlee, D.K., and Mudgett, P.D., "Chemical Characterization of U.S. Laboratory Humidity Condensate," SAE 2006-01-2016, SAE 36 ${ }^{\text {th }}$ International Conference on Environmental Systems, Norfolk, Virginia, 2006.

Philistine, C.L. and Kulhanjian, A., "International Space Station Water Usage Analysis," SAE 2006-01-2094, SAE 36 ${ }^{\text {th }}$ International Conference on Environmental Systems, Norfolk, Virginia, 2006.

Straub, J.E., Plumlee, D., and Shultz, J., "Sampling and Chemical Analysis of Potable Water for ISS Expeditions 12 and 13," SAE 2007-01-3214, SAE 37th International Conference on Environmental Systems, Chicago, Illinois, 2007.

Shkedi, B., "Lessons Learned from the International Space Station Environmental Control and Life Support System Water Subsystem," SAE 2008-01-2008, SAE $38^{\text {th }}$ International Conference on Environmental Systems, San Francisco, California, 2008.

Kulhanjian, A., Yeoman, D., and Philistine, C., "International Space Station Water Usage Analysis," SAE 2008-01-2009, SAE $38^{\text {th }}$ International Conference on Environmental Systems, San Francisco, California, 2008.

Carter, D.L., Tabb, D., and Perry, J., "Evaluation of an Exploration Water Recovery System Architecture," SAE 2008-012140, SAE $38^{\text {th }}$ International Conference on Environmental Systems, San Francisco, California, 2008.

Straub, J.E., Plumlee, D.K., and Shultz, J.R., "Chemical Analysis Results for Potable Water Returned from ISS Expeditions 14 and 15," SAE 2008-01-2197, SAE 38 $8^{\text {th }}$ International Conference on Environmental Systems, San Francisco, California, 2008. 
Carter, D.L., "Status of the Regenerative ECLSS Water Recovery System," SAE 2009-01-2352, SAE 39"h International Conference on Environmental Systems, Savannah, Georgia, 2009.

Straub, J., Plumlee, D., and Schultz, J., "ISS Expeditions 16 through 20: Chemical Analysis Results for Potable Water," AIAA-2010-6042, AIAA 40 th International Conference on Environmental Systems, Barcelona, Spain, 2010.

Carter, L., Hagos, M., and Sitler, G., "Status of the Regenerative ECLSS Water Recovery System," AIAA-2010-6216, AIAA $40^{\text {th }}$ International Conference on Environmental Systems, Barcelona, Spain, 2010.

Straub, J., Plumlee, D., Shultz, J., and McCoy, J., "Chemical Analysis Results for Potable Water from ISS Expeditions 21 through 25," AIAA-2011-5152, AIAA 41 ${ }^{\text {st }}$ International Conference on Environmental Systems, Portland, Oregon, 2011.

Schultz, J, Rutz, J., Kuo, C, Cole, H., Manuel, S., Curtis, M., Jones, P., Sparkman, O., and McCoy, J., "Discovery and Identification of Dimethylsilanediol as a Contaminant in ISS Potable Water," AIAA-2011-5154, AIAA 41 ${ }^{\text {st }}$ International Conference on Environmental Systems, Portland, Oregon, 2011.

Carter, D., "Status of ISS Water Management and Recovery," AIAA-2011-5223, AIAA 41 Int International Conference on Environmental Systems, Portland, Oregon, 2011.

Straub, J., Plumlee, D., Shultz, J., and McCoy, J., "Potable Water Quality for International Space Station Expeditions 30-33," AIAA-2013-3310, AIAA 43 ${ }^{\text {rd }}$ International Conference on Environmental Systems, Vail, Colorado, 2013.

Carter, D., Tobias, B., and Orozco, N., "Status of ISS Water Management and Recovery," AIAA-2013-3509, AIAA 43 ${ }^{\text {rd }}$ International Conference on Environmental Systems, Vail, Colorado, 2013.

Carter, D., Bowman, E., Wilson, M., and Rector, T., "Investigation of DMSD Trend in ISS Water Processor Assembly," AIAA-2013-3510, AIAA 43 ${ }^{\text {rd }}$ International Conference on Environmental Systems, Vail, Colorado, 2013.

Straub, J.E., Plumlee, D.K., Schultz, J.R., and Mudgett, P.D., "International Space Station Water Characterization for 2013," ICES-2014-190, 44 th International Conference on Environmental Systems, Tucson, Arizona, 2014.

Carter, D., Pruitt, J., Brown, C., Bankers, L., and Schaezler, R., "Status of ISS Water Management and Recovery," ICES2015-73, 45 th International Conference on Environmental Systems, Bellevue, Washington, 2015.

Carter, D., Pruitt, J., Bagdigian, R., and Kayatin, M., "Upgrades to the ISS Water Recovery System," ICES-2015-133, 45 International Conference on Environmental Systems, Bellevue, Washington, 2015.

Straub, J.E., Plumlee, D.K., Gazda, D.B., and Wallace, W.T., "Chemical Characterization and Identification of Organosilicon Contaminants in ISS Potable Water," ICES-2016-416, 46 ${ }^{\text {th }}$ International Conference on Environmental Systems, Vienna, Austria, 2016.

Carter, D., Schaezler, R., Bankers, L., Gazda, D., Brown, C., Bazley, J., and Pruitt, J., "Status of ISS Water Management and Recovery," ICES-2016-17, 46 ${ }^{\text {th }}$ International Conference on Environmental Systems, Vienna, Austria, 2016.

Kayatin, M., Carter, D., Pruitt, J., and Schunk, R., "Upgrades to the ISS Water Recovery System," ICES-2016-16, 46 ${ }^{\text {th }}$ International Conference on Environmental Systems, Vienna, Austria, 2016.

\section{Environmental Monitoring}

Reysa, R.P., Granahan, J.E., Steiner, G., Ransom, E., "International Space Station Major Constituent Analyzer On-Orbit Performance," SAE 2004-01-2546, SAE 34 $4^{\text {th }}$ International Conference on Environmental Systems, Colorado Springs, Colorado, 2004.

Steiner, G., McHard, R.W., Granahan, J., and Reysa, R.P., "Accuracy Assessment of the Major Constituent Analyzer," SAE 2005-01-2893, SAE 35 $5^{\text {th }}$ International Conference on Environmental Systems and $8^{\text {th }}$ European Symposium on Space Environmental Control Systems, Rome, Italy, 2005.

Steiner, G., Maleki-Thoresen, S., Reysa, R.P., and Granahan, J., "International Space Station Major Constituent Analyzer On-Orbit Performance," SAE 2006-01-2092, SAE $36^{\text {th }}$ International Conference on Environmental Systems, Norfolk, Virginia, 2006.

Granahan, J.E. and Thoresen, S.M., "Major Constituent Analyzer Mass Spectrometer Operating Life Improvements," SAE 2008-01-1966, SAE 38 ${ }^{\text {th }}$ International Conference on Environmental Systems, San Francisco, California, 2008.

Steiner, G., "International Space Station Major Constituent Analyzer On-Orbit Performance," SAE 2008-01-1971, SAE 38 International Conference on Environmental Systems, San Francisco, California, 2008.

Jan, D., "Environmental Monitoring as Part of Life Support for the Crew Habitat for Lunar and Mars Missions," AIAA-20106092, AIAA 40 ${ }^{\text {th }}$ International Conference on Environmental Systems, Barcelona, Spain, 2010.

Gardner, B., Granahan, J., Erwin, P, and Thoresen, S., "International Space Station Major Constituent Analyzer On-Orbit Performance," AIAA-2010-6233, AIAA 40 ${ }^{\text {th }}$ International Conference on Environmental Systems, Barcelona, Spain, 2010.

Gardner, B., Thoresen, S., Granahan, J., Belcher, P., and Matty, C., "Hardware Design Improvements to the Major Constituent Analyzer," AIAA-2011-5129, AIAA 41 ${ }^{\text {st }}$ International Conference on Environmental Systems, Portland, Oregon, 2011.

Gardner, B., Erwin, P., and Thoresen, S., "International Space Station Major Constituent Analyzer On-Orbit Performance," ICES-2015-255, 45 ${ }^{\text {th }}$ International Conference on Environmental Systems, Bellevue, Washington, 2015.

Gardner, B., Erwin, P., Chladek, R., and Matty, C., "International Space Station Major Constituent Analyzer On-Orbit Performance," ICES-2016-362, 46 ${ }^{\text {th }}$ International Conference on Environmental Systems, Vienna, Austria, 2016.

\section{Logistics Management}

Williams, D.E., "Summary of Resources for the International Space Station Environmental Control and Life Support System," SAE 2003-01-2596, SAE 33 ${ }^{\text {rd }}$ International Conference on Environmental Systems, Vancouver, British Columbia, Canada, 2003. 
Thompson, D., "ISS ECLSS Expendable Service Life Improvements," SAE 2003-01-2492, SAE 33 ${ }^{\text {rd }}$ International Conference on Environmental Systems, Vancouver, British Columbia, Canada, 2003.

Thompson, C.D. and Shkedi, B., "ISS ECLSS: 3 Years of Logistics for Maintenance," SAE 2004-01-2388, SAE 34th International Conference on Environmental Systems, Colorado Springs, Colorado, 2004.

Bagdigian, R., Dake, J., Gentry, G., and Gault, M., "International Space Station Environmental Control and Life Support System Mass and Crewtime Utilization in Comparison to a Long Duration Human Space Exploration Mission," ICES-2015-94, $45^{\text {th }}$ International Conference on Environmental Systems, Bellevue, Washington, 2015.

Schaezler, R., "Report on ISS Oxygen Production, Gas Resupply, and Partial Pressure Management," ICES-2015-146, 45 th International Conference on Environmental Systems, Bellevue, Washington, 2015.

\section{System Testing, Status, and Lessons Learned}

Gentry, G.J. and Edeen, M.A., "International Space Station ECLS On-orbit Hardware Failures and Causes," SAE 2002-012495, SAE 32 $2^{\text {nd }}$ International Conference on Environmental Systems, San Antonio, Texas, 2002.

Reuter, J.L., "International Space Station Environmental Control and Life Support System Status: 2001-2002," SAE 200201-2494, SAE 32 ${ }^{\text {nd }}$ International Conference on Environmental Systems, San Antonio, Texas, 2002.

Reuter, J.L. and Reysa, R.P., "International Space Station Environmental Control and Life Support System Status: 20002001," SAE 2001-01-2386, SAE 31 ${ }^{\text {st }}$ International Conference on Environmental Systems, Orlando, Florida, 2001.

Reuter, J.L., "International Space Station Environmental Control and Life Support System Status: 1999-2000," SAE 200001-2248, SAE 30 ${ }^{\text {th }}$ International Conference on Environmental Systems and $7^{\text {th }}$ European Symposium on Space Environmental Control Systems, Toulouse, France, 2000.

Wentz, G.L., "International Space Station Environmental Control and Life Support System Verification and Test Program for the United States Laboratory Element, SAE 2000-01-2294, SAE $30^{\text {th }}$ International Conference on Environmental Systems and $7^{\text {th }}$ European Symposium on Space Environmental Control Systems, Toulouse, France, 2000.

Williams, D.E., "International Space Station Environmental Control and Life Support System Status: 2002-2003," SAE 2003-01-2589, SAE 33 ${ }^{\text {rd }}$ International Conference on Environmental Systems, Vancouver, British Columbia, Canada, 2003.

Williams, D.E. and Gentry, G.J., "International Space Station Environmental Control and Life Support System Status: 20032004," SAE 2004-01-2382, SAE 34 ${ }^{\text {th }}$ International Conference on Environmental Systems, Colorado Springs, Colorado, 2004.

Gentry, G.J. and Williams, D.E., "International Space Station Environmental Control and Life Support System Overview of On-Board Events February 2002-February 2004," SAE 2004-01-2383, SAE 34 ${ }^{\text {th }}$ International Conference on Environmental Systems, Colorado Springs, Colorado, 2004.

Williams, D.E. and Gentry, J.G., "International Space Station Environmental Control and Life Support System Status: 20042005," SAE 2005-01-2777, SAE 35 th International Conference on Environmental Systems and $8^{\text {th }}$ European Symposium on Space Environmental Control Systems, Rome, Italy, 2005.

Gentry, G.J., "International Space Station Environmental Control and Life Support System Overview of Events: February 2004-February 2005," SAE 2005-01-2778, SAE 35 th International Conference on Environmental Systems and $8^{\text {th }}$ European Symposium on Space Environmental Control Systems, Rome, Italy, 2005.

Williams, D.E., "International Space Station Environmental Control and Life Support System Status: 2005-2006," SAE 2006-01-2055, SAE 36 ${ }^{\text {th }}$ International Conference on Environmental Systems, Norfolk, Virginia, 2006.

Gentry, G.J. and Williams, D., "International Space Station Environmental Control and Life Support System Overview of Events: February 2005-2006," SAE 2006-01-2056, SAE $36^{\text {th }}$ International Conference on Environmental Systems, Norfolk, Virginia, 2006.

Williams, D.E., "International Space Station Environmental Control and Life Support System Status: 2006-2007," SAE 2007-01-3098, SAE 37th International Conference on Environmental Systems, Chicago, Illinois, 2007.

Gentry, G.J. and Williams, D.E., "International Space Station Environmental Control and Life Support System Overview of On-board Events February 2006-February 2007," SAE 2007-01-3099, SAE 37 th International Conference on Environmental Systems, Chicago, Illinois, 2007.

Williams, D.E., "International Space Station Environmental Control and Life Support System Status: 2007-2008," SAE 2008-01-2131, SAE 38 ${ }^{\text {th }}$ International Conference on Environmental Systems, San Francisco, California, 2008.

Gentry, G. and Reysa, R.P., "International Space Station Environmental Control and Life Support System Overview of Events February 2007-2008," SAE 2008-01-2132, SAE 38 ${ }^{\text {th }}$ International Conference on Environmental Systems, San Francisco, California, 2008.

Williams, D.E., "International Space Station Environmental Control and Life Support System Status: 2008-2009," SAE 2009-01-2415, SAE 39th International Conference on Environmental Systems, Savannah, Georgia, 2009.

Williams, D., Dake, J., and Gentry, G., "International Space Station Environmental Control and Life Support System Status: 2009-2010," AIAA-2010-6180, AIAA 40 ${ }^{\text {th }}$ International Conference on Environmental Systems, Barcelona, Spain, 2010.

Williams, D., Gentry, G., and Dake, J., "International Space Station Environmental Control and Life Support System Status for the Prior Year: 2010-2011," AIAA-2012-3612, AIAA 42 ${ }^{\text {nd }}$ International Conference on Environmental Systems, San Diego, California, 2012.

Gentry, G. and Cover, J., "International Space Station Environmental Control and Life Support System Overview of Events: 2010-2014," ICES-2015-155, 45 th International Conference on Environmental Systems, Bellevue, Washington, 2015.

Gentry, G., "International Space Station Environmental Control and Life Support System Overview of Events: 2014-2015," ICES-2016-406, 46 $6^{\text {th }}$ International Conference on Environmental Systems, Vienna, Austria, 2016. 


\section{Acknowledgments}

This work is conducted by the Life Support Systems Project under the sponsorship of NASA's Advanced Exploration Systems Program.

\section{References}

${ }^{1}$ International Space Exploration Coordination Group, The Global Exploration Strategy: The Framework for Coordination, May 2007.

${ }^{2}$ National Space Policy of the United States of America, June 28, 2010, p. 4.

${ }^{3}$ Ibid. p. 11.

${ }^{4}$ International Space Exploration Coordination Group, The Global Exploration Roadmap, NASA NP-2013-06-945-HQ, August 2013.

${ }^{5}$ NASA's Journey to Mars: Pioneering Next Steps in Space Exploration, NP-2015-08-2018-HQ, NASA, Washington, DC, October 2015.

${ }^{6}$ Human Exploration of Mars Design Reference Architecture 5.0, NASA-SP-2009-566, National Aeronautics and Space Administration, July 2009.

${ }^{7}$ Human Exploration of Mars Design Reference Architecture 5.0 Addendum, NASA/SP-2009-566-ADD, National Aeronautics and Space Administration, July 2009.

${ }^{8}$ Human Exploration of Mars Design Reference Architecture 5.0 Addendum \#2, NASA-SP-2009-566-ADD2, National Aeronautics and Space Administration, March 2014.

${ }^{9}$ Voyages - Charting the Course for Sustainable Human Space Exploration, NP-2011-06-395-LaRC, National Aeronautics and Space Administration, 2011, p. 26.

${ }^{10}$ NASA Space Technology Roadmaps and Priorities: Restoring NASA's Technological Edge and Paving the Way for a New Era in Space, The National Academies Press, Washington, DC, 2012, pp. 6, 12, 36, 184.

${ }^{11}$ NASA Technology Roadmaps TA 6: Human Health, Life Support, and Habitation Systems, NASA, Washington, DC, 2015, pp. 19-20.

${ }^{12}$ Ibid. pp. 23-29, 51-54.

${ }^{13}$ Howard, D., Perry, J., Sargusingh, M., and Toomarian, N., "Notional Environmental Control and Life Support System Architectures for Human Exploration beyond Low-Earth Orbit," AIAA-2015-4456, AIAA SPACE 2015, Pasadena, California, 2015.

${ }^{14}$ Hodgson, E., Converse, D., Duggan, M., and Gentry, G. "Flexible Path Environmental Control and Life Support Technology-Possible First Steps to Move Beyond LEO," AIAA-2012-3443, AIAA 42 ${ }^{\text {nd }}$ International Conference on Environmental Systems, San Diego, CA, 2012

${ }^{15}$ Hodgson, E., Converse, D., Duggan, M., and Gentry, G. "Flexible Path Environmental Control and Life Support Technology-An Updated Look at Next Steps," AIAA-2013-3409, AIAA 43 ${ }^{\text {rd }}$ International Conference on Environmental Systems, Vail, Colorado, 2013.

${ }^{16}$ Howard, D., Perry, J., Sargusingh, M., and Toomarian, N., "Notional Environmental Control and Life Support System Architectures for Human Exploration beyond Low-Earth Orbit," AIAA-2015-4456, AIAA SPACE 2015, Pasadena, California, 2015.

${ }^{17}$ Perry, J.L., Sargusingh, M.J., and Toomarian, N., "Functional Interface Considerations within an Exploration Life Support System Architecture," ICES-2016-90, 46 ${ }^{\text {th }}$ International Conference on Environmental Systems, Vienna, Austria, 2016.

${ }^{18}$ Bagdigian, R., Gatens, R., Metcalf, J., Stephan, r., Broyan, J., Shull, S., and Macatangay, A., "National Aeronautics and Space Administration Environmental Control and Life Support Technology Development and Maturation for Exploration," ICES-2014-19, 44th International Conference on Environmental Systems, Tucson, Arizona, 2014.

${ }^{19}$ Gatens, R.L., Anderson, M.S., Broyan, J.L., Macatangay, A.V., Shull, S.A., Perry, J.L., Schneider, W.F., and Toomarian, N.B., "National Aeronautics and Space Administration Environmental Control and Life Support Technology Development and Maturation for Exploration: 2014 to 2015 Overview," ICES-2015-111, 45 th International Conference on Environmental Systems, Bellevue, Washington, 2015.

${ }^{20}$ Schneider, W., Perry, J., Anderson, M., Broyan, J., Macatangay, A., Shull, S., Gatens, R., and Toomarian, N., "NASA Environmental Control and Life Support Technology Development and Maturation for Exploration: 2015 to 2016 Overview," ICES2016-40, 46 ${ }^{\text {th }}$ International Conference on Environmental Systems, Vienna, Austria, 2016.

${ }^{21}$ Human Exploration of Mars Design Reference Architecture 5.0, NASA-SP-2009-566, National Aeronautics and Space Administration, July 2009, pp. 47-48.

${ }^{22}$ Human Exploration of Mars Design Reference Architecture 5.0 Addendum, NASA/SP-2009-566-ADD, National Aeronautics and Space Administration, July 2009, pp. 49-51, 65.

${ }^{23}$ Ibid. pp. 148-155.

${ }^{24}$ Human Exploration of Mars Design Reference Architecture 5.0 Addendum \#2, NASA/SP-2009-566-ADD2, National Aeronautics and Space Administration, March 2014, pp. 367-371.

${ }^{25}$ Smitherman, D. and Griffin, B.N., "Habitat Concepts for Deep Space Exploration," AIAA 2014-4477, AIAA SPACE 2014 Conference and Exposition, San Diego, California, 2014.

${ }^{26}$ Human Exploration of Mars Design Reference Architecture 5.0 Addendum \#2, NASA-SP-2009-566-ADD2, National Aeronautics and Space Administration, March 2014, pp. 399, 402.

${ }^{27}$ Human Exploration of Mars Design Reference Architecture 5.0 Addendum, NASA/SP-2009-566-ADD, National Aeronautics and Space Administration, July 2009, p. 46.

18

American Institute of Aeronautics and Astronautics 
${ }^{28}$ Human Integration Design Handbook, NASA/SP-2010-3407, NASA, Washington, D.C., January 27, 2010, pp. 337-9.

${ }^{29}$ NASA Space Flight Human-System Standard Volume 2: Human Factors, Habitability, and Environmental Health, NASASTD-3001, Volume 2, Revision A, NASA, Washington, D.C., February 10, 2015, p. 27.

${ }^{30}$ Perry, J.L., "A Design Basis for Spacecraft Cabin Trace Contaminant Control," SAE 2009-01-2592, SAE 39 $9^{\text {th }}$ International Conference on Environmental Systems, Savannah, Georgia, 2009.

${ }^{31}$ Perry, J.L. and Kayatin, M.J., "Trace Contaminant Control Design Considerations for Enabling Exploration Missions," ICES 2015-108, 45 th International Conference on Environmental Systems, Bellevue, Washington, 2015.

${ }^{32}$ Perry, J.L. and Kayatin, M.J., "The Fate of Trace Contaminants in a Crewed Spacecraft Cabin Environment," ICES-201691, 46 $6^{\text {th }}$ International Conference on Environmental Systems, Vienna, Austria, 2016.

${ }^{33}$ Satish, U., Mendell, M.J., Shekhar, K., Hotchi, T., Sullivan, D., Streufert, S., and Fisk, W.J., Is $\mathrm{CO}_{2}$ an Indoor Pollutant? Direct Effects of Low-to-Moderate $\mathrm{CO}_{2}$ Concentrations on Human Decision-Making Performance, Environmental Health Perspectives, National Institutes of Health, September 20, 2012.

${ }^{34}$ James, J.T. and Zalesak, S.M., "Surprising Effects of $\mathrm{CO}_{2}$ Exposure on Decision Making," AIAA 2013-3463, AIAA 43rd International Conference on Environmental Systems, Vail, Colorado, 2013.

${ }^{35}$ Law, J., Baalen, M.V., Foy, M., Mason, S.S., Mendez, C., Wear, M.L., Meyers, V.E., and Alexander, D., Relationship Between Carbon Dioxide Levels and Reported Headaches on the International Space Station, JEOM, 56 (5), 2014 , pp. 481-482.

${ }^{36}$ Agui, J.H., Vijayakumar, R., and Perry, J.L., "Particulate Matter Filtration Design Considerations for Crewed Spacecraft Life Support Systems, ICES-2016-93, 46 ${ }^{\text {th }}$ International Conference on Environmental Systems, Vienna, Austria, 2015 , p. 2.

${ }^{37}$ Meyer, M., "ISS Ambient Air Quality: Updated Inventory of Known Aerosol Sources," ICES-2014-199, 44 ${ }^{\text {th }}$ International Conference on Environmental Systems, Tucson, Arizona, 2014, p. 7.

${ }^{38}$ Human Integration Design Handbook, NASA/SP-2010-3407, NASA, Washington, D.C., January 27, 2010 , p. 343.

${ }^{39}$ NASA Space Flight Human-System Standard Volume 2: Human Factors, Habitability, and Environmental Health, NASASTD-3001, Volume 2, Revision A, NASA, Washington, D.C., February 10, 2015, p. 43.

${ }^{40}$ NASA Space Flight Human-System Standard Volume 2: Human Factors, Habitability, and Environmental Health, NASASTD-3001, Volume 2, Revision A, NASA, Washington, D.C., February 10, 2015, p. 26

${ }^{41}$ Ibid. p. 27.

${ }^{42}$ Recommendations for Exploration Spacecraft Internal Atmospheres: The Final Report of the NASA Exploration Atmospheres Working Group, NASA/TP-2010-216134, October 2010, p. 16.

${ }^{43}$ Human Integration Design Handbook, NASA/SP-2010-3407, NASA, Washington, D.C., January 27, 2010, pp. $357-9$.

${ }^{44}$ Ibid. p. 360.

${ }^{45}$ NASA Space Flight Human-System Standard Volume 2: Human Factors, Habitability, and Environmental Health, NASASTD-3001, Volume 2, Revision A, NASA, Washington, D.C., February 10, 2015, p. 36.

${ }^{46}$ Ibid. p. 36.

${ }^{47}$ Human Integration Design Handbook, NASA/SP-2010-3407, NASA, Washington, D.C., January 27, 2010, pp. $362-3$.

${ }^{48}$ Pace, G.S., Fisher, J., Delzeit, L., Alba, R.G., and Wignarajah, K., "Development of the Heat Melt Compactor for Waste Management during Long Duration Human Space Missions," AIAA 2012-3545, 42 ${ }^{\text {nd }}$ ICES, San Diego, 2012, p. 2.

${ }^{49}$ NASA Space Flight Human-System Standard Volume 2: Human Factors, Habitability, and Environmental Health, NASASTD-3001, Volume 2, Revision A, NASA, Washington, D.C., February 10, 2015, p. 82.

${ }^{50}$ Ibid. p. 80.

${ }^{51}$ Rose, C., Parker, A., Jefferson, B., and Cartmell, E., The Characterization of Feces and Urine: A Review of the Literature to Inform Advanced Treatment Technology, Critical Reviews in Environmental Science and Technology, 45:1827-1879, 2015.

${ }^{52}$ Howard, D., Perry, J., Sargusingh, M., and Toomarian, N., "Notional Environmental Control and Life Support System Architectures for Human Exploration beyond Low-Earth Orbit," AIAA-2015-4456, AIAA SPACE 2015, Pasadena, California, 2015, pp. 10-11.

${ }^{53}$ NASA Space Flight Human-System Standard Volume 2: Human Factors, Habitability, and Environmental Health, NASASTD-3001, Volume 2, Revision A, NASA, Washington, D.C., February 10, 2015, p. 26.

${ }^{54}$ Ibid. p. 34

${ }^{55}$ Ibid. p. 34.

${ }^{56}$ Human Exploration of Mars Design Reference Architecture 5.0 Addendum \#2, NASA-SP-2009-566-ADD2, National Aeronautics and Space Administration, March 2014,

${ }^{57}$ Goforth, M.B., Ratliff, J.E., Hames, K.L., Vitalpur, S.V., “Avionics Architectures for Exploration: Building a Better Approach for Human Spaceflight Avionics,” AIAA 2014-1604, AIAA SpaceOps 2014 Conference, Pasadena, California, 2014, pp. $1,15$.

${ }^{58}$ Krupiarz, C., "The Road to the New Flight Software,” Ask Magazine, Summer, 2013, pp. 33-36.

${ }^{59}$ NASA Study on Flight Software Complexity, 2009, p. 2.

${ }^{60}$ Goforth, M.B., Ratliff, J.E., Hames, K.L., Vitalpur, S.V., “Avionics Architectures for Exploration: Building a Better Approach for Human Spaceflight Avionics," AIAA 2014-1604, AIAA SpaceOps 2014 Conference, Pasadena, California, 2014, pp. 2.

${ }^{61}$ Human Exploration of Mars Design Reference Architecture 5.0 Addendum \#2, NASA-SP-2009-566-ADD2, National Aeronautics and Space Administration, March 2014, p. 369.

${ }^{62}$ Human Exploration of Mars Design Reference Architecture 5.0 Addendum, NASA/SP-2009-566-ADD, National Aeronautics and Space Administration, July 2009, pp. 45-46. 